\title{
Nature's contributions to people: coproducing quality of life from multifunctional landscapes
}

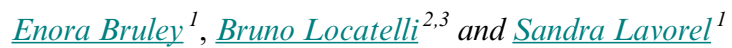

\begin{abstract}
Nature's contributions to human well-being within social-ecological systems have been widely studied using multiple conceptual frameworks, yet there is a growing need to better articulate how both humans and nature contribute to quality of life. We present an operationalization of the Intergovernmental Platform on Biodiversity and Ecosystem Services (IPBES) conceptual framework with an in-depth analysis of the coproduction of nature's contributions to people (NCP) in a mountain social-ecological system. Based on a participatory process questioning stakeholders on nature's contributions to their quality of life, we propose an analysis of NCP coproduction mechanisms in a multifunctional landscape. We refine the consideration of NCP coproduction in the IPBES framework by distinguishing three coproduction types at different steps of the benefits flow from ecosystems to quality of life: (1) ecosystem management; (2) mobilization, harvesting, and physical access; and (3) appropriation, social access, and appreciation. For each of these coproduction types, we describe the types of natural and human-derived capital involved. This approach highlights: nature's key contributions to people as perceived by participants; landscape multifunctionality and interlinkages among NCP induced by their simultaneous coproduction to improve quality of life; and a gradient of natural and human-derived capital among coproduction types and among material, nonmaterial, and regulating NCP. This approach documents how NCP coproduction creates social-ecological trade-offs and synergies among multiple NCP, as well as collaborations and conflicts among beneficiaries at the landscape level. We conclude that the analysis of NCP coproduction can provide new opportunities for ecosystem services research by tackling the involvement of both humans and nature in quality of life objectives.
\end{abstract}

Key Words: agriculture; coproduction; ecosystem services; landscape; mountain; quality of life; social-ecological system

\section{INTRODUCTION}

Understanding complex interactions between nature and society is still a challenge as regards informing sustainable development (Steffen et al. 2015). Multiple social-ecological approaches and conceptual frameworks have blossomed over the past two decades (Berkes et al. 2002, Liu et al. 2007, Ostrom 2009, Collins et al. 2011, Binder et al. 2013). They depict the interlinkages between the social and natural processes that drive the delivery of benefits from nature to people and underpin the functioning of socialecological systems (Millennium Ecosystem Assessment 2005, Haines-Young and Potschin 2010, Reyers et al. 2013, Ellis et al. 2019). An example is the conceptual framework of the Intergovernmental Platform on Biodiversity and Ecosystem Services (IPBES; Díaz et al. 2015), which divides social-ecological systems into six main components (nature, nature's contributions to people [NCP], good quality of life, anthropogenic assets, direct drivers of change, and indirect drivers of change) and 10 interactions. Similar to ecosystem services, NCP is defined as "all the contributions, both positive and negative, of living nature (diversity of organisms, ecosystems, and their associated ecological and evolutionary processes) to people's quality of life" (Díaz et al. 2018).

In the IPBES framework, good quality of life is the accomplishment of a "fulfilled human life" (Díaz et al. 2015) and encompasses individual aspirations of access to food, water, health, education, and livelihood security; social goals of diversity of options, environmental justice, and intra- and intergenerational equity; and cultural dimensions of identity and autonomy, spirituality and religions, and arts and cultural heritage (Pascual et al. 2017). Nature refers to the diversity of living organisms and their interactions among themselves and with their environment (Díaz et al. 2015). Nature contributes to quality of life through material, nonmaterial, and regulating NCP (Díaz et al. 2018), which are affected by natural or anthropogenic direct drivers. Natural direct drivers are natural processes linked to climate or disturbances that are not directly human activities, such as extreme rainfall or pest outbreaks that will directly affect agricultural productivity. Anthropogenic direct drivers are those resulting from human decisions and actions, such as pollution, climate change, and ecosystem restoration. Indirect drivers are related to changes that are external to the social-ecological system, such as economic, demographic, cultural, or lifestyle changes (Martín-López et al. 2019), for example, consumption patterns and markets that influence demand for NCP. Institutions and governance are also considered indirect drivers of how decisions are made and implemented and how people and societies organize themselves and their interactions with nature (Díaz et al. 2015), for example, public policies relating to land use and management. Finally, anthropogenic assets represent all infrastructures, financial assets, knowledge, skills, and technologies involved in the coproduction of NCP.

Since the Millennium Ecosystem Assessment (2005), the coproduction of ecosystem services by people and nature has gained stronger recognition (Mastrángelo et al. 2019). The IPBES framework brings to the fore the role of humans in the provision of NCP by recognizing the role of anthropogenic assets in good quality of life through the coproduction of benefits between nature and various assets built by people (Díaz et al. 2015).

${ }^{1}$ Laboratoire d'Ecologie Alpine, UMR 5553 CNRS - Université Grenoble Alpes - Université Savoie Mont-Blanc, 38000 Grenoble, France, ${ }^{2}$ Cirad, University of Montpellier, France, ${ }^{3}$ Cifor, Lima, Peru 
Whereas ecosystem services are often treated in scientific analyses and common discourse as a "free gift of nature" (Spangenberg et al. 2014), they are usually jointly produced by social-ecological processes and require human intervention to deliver a benefit, a process referred to as coproduction (Palomo et al. 2016). Although ecological factors that drive service provision have been addressed extensively, the assessment of human factors has remained marginal (Mastrángelo et al. 2019) yet is critical to understanding complex social-ecological systems. This notion of coproduction has been integrated into recent social-ecological frameworks (Lele et al. 2013, Reyers et al. 2013), and various approaches to coproduction have been proposed: Spangenberg et al. (2014) conceptualized how human agency shapes ecosystem services provision along the ecosystem services flow from ecosystems to human well-being, and Fischer and Eastwood (2016) proposed an analytical framework for the role of humans in the generation of ecosystem services focusing on people's identities and capabilities. In addition, analytical approaches to coproduction have been developed and applied to exemplary case studies. For example, Jones et al. (2016) and Palomo et al. (2016) proposed to analyze the natural and human-derived capital involved in ecosystem services delivery flow, thereby highlighting trade-offs among natural and human-derived capital along gradients of management intensification (Outeiro et al. 2017). Fedele et al. (2017) characterized the mechanisms mediating the contribution of ecosystem services to human well-being along the ecosystem services benefits flow: management, mobilization, allocation appropriation, and appreciation.

To date, the notion of coproduction of NCP has been underdeveloped in IPBES reports and in papers using its framework (e.g., IPBES 2019, Martín-López et al. 2019), and the priority question of how ecosystem services are coproduced by social-ecological systems (Bennett et al. 2015) still stands out as a knowledge gap (Mastrángelo et al. 2019). Thus, although coproduction is at the core of frameworks such as that of IPBES, coproduction mechanisms need to be analyzed more explicitly by considering human inputs at all steps of benefit production from ecosystems to NCP and quality of life. Here, we address this gap by applying the IPBES framework with a focus on coproduction mechanisms underpinning NCP. In a mountain social-ecological system of the French Alps, we aimed to understand the humannature interactions that make up the local social-ecological system. We used the IPBES framework to guide a participatory process and as an analytical framework to identify nature's contributions to good quality of life and the drivers that shape the interactions perceived by stakeholders. We present how this process led us to enhance the representation of NCP coproduction within the IPBES framework for analyzing human-derived capital that is involved at different steps along the flow of NCP from ecosystems to people. With this novel specification of coproduction, we asked four questions: (1) What are the key contributions of nature to good quality of life in this mountain social-ecological system? (2) How are NCP and benefits for quality of life coproduced? (3) What human-derived capital is involved in NCP coproduction for quality of life? (4) How can the analysis of NCP coproduction provide new opportunities for ecosystem services assessment, particularly through the IPBES conceptual framework?

\section{METHODS}

\section{Case study description}

In the central French Alps, Pays de la Meije, located at the head of the Romanche Valley, is a remote valley with an area of 205 $\mathrm{km}^{2}$ at an altitude varying between 1135 and $3984 \mathrm{~m}$. The climate is alpine with Mediterranean influences (mean minimum temperature $-7.4^{\circ} \mathrm{C}$ [February], mean maximum temperature $19.5^{\circ} \mathrm{C}$ [July]; mean annual precipitation $956 \mathrm{~mm}$ with $60 \%$ as winter snowfall; growing season: mid-April to mid-October [Quétier et al. 2007]). South-facing slopes are dominated by terraced grasslands and summer pastures shaped since the late Middle Ages by traditional farming, with livestock production as a predominant activity since the early 20th century. Mowing and grazing maintain a grassy landscape with terraces as a legacy (Quétier et al. 2007). North-facing slopes are characterized by steeper slopes covered by forest below $2200 \mathrm{~m}$ and sparse vegetation, rocks, and ice at higher altitude that are mainly included in the core area of the Ecrins National Park and a skiing area (Fig. 1; Table A1.1 in Appendix 1).

With two municipalities, La Grave (484 inhabitants) and Villar d'Arène (322 inhabitants; Institut national de la statistique et des etudes économiques, 2016: https://www.insee.fr/fr/accueil), Pays de la Meije has a low-density population $\left(<5\right.$ inhabitants $\left./ \mathrm{km}^{2}\right)$ that is stable and concentrated in two villages and seven hamlets with numerous secondary and touristic residences $(\sim 60 \%$ of the accommodation capacity). The local economy is based on tourism linked to mountain sports such as off-track skiing, hiking, climbing, and road- and mountain-biking, and to cultural tourism. The three main tourism attractions are the cable car of La Grave, the Ecrins National Park, and the Lautaret Alpine botanical garden. Tourism is also an essential component of the local economy because it provides off-farm jobs and income (Schermer et al. 2016). Agriculture is still important for the local economy, with a traditional mountain livestock farming system based on fodder self-sufficiency and summer transhumance (Schermer et al. 2016). The region is currently experiencing new agricultural dynamics, with the installation of young farmers in livestock production or market gardening. Local life is also highly dependent on surrounding regions, particularly in terms of jobs (in nearby ski resorts) and residential services (education, health, retail). Local governance is mainly organized at the municipality level, but as elsewhere in France, it is increasingly devolved to councils of municipalities, here the "Communauté de Communes du Briançonnais" (13 municipalities comprising 20,987 inhabitants and $844 \mathrm{~km}^{2}$ ).

\section{Data collection}

To elicit actors' perceptions of their interactions with nature, we applied a three-step participatory process: first, to discuss quality of life and describe human-nature interactions in general; second, to refine the description of individual and collective quality of life dimensions; and third, to confirm the overall understanding of the social-ecological system that emerged from the first two steps. To capture stakeholders' perceptions and to avoid influencing their thinking, we did not introduce any conceptual framework or scientific terminology to the participatory activities. For example, we did not use terms such as ecosystem services or nature benefits, and we did not present a predefined list of NCP. However, we used the term "nature's contribution to 
Fig. 1. Map of the study area and land-cover typology.

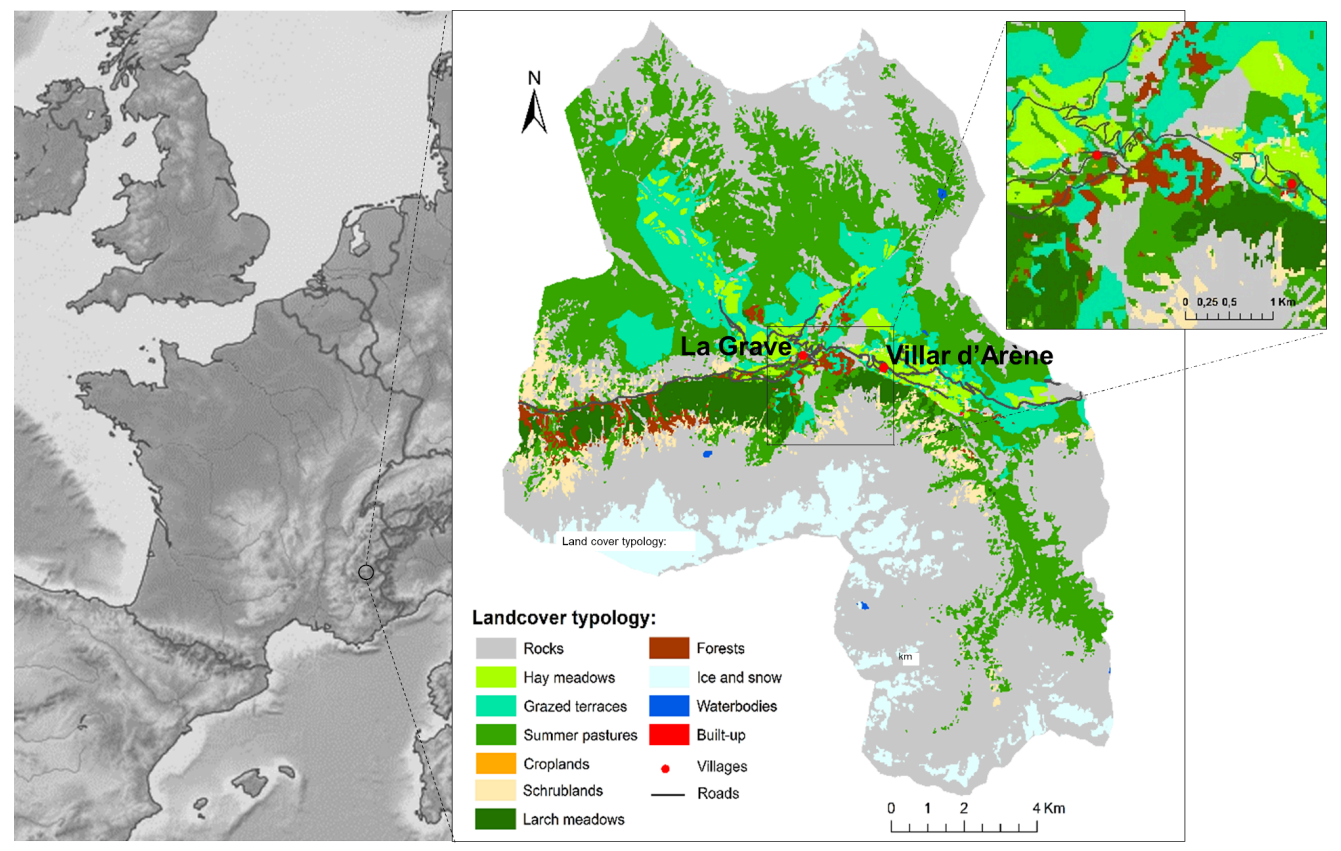

..." by specifying the purpose of the contribution using phrases such as: "nature's contribution to quality of life, daily life, or economic activities", and the "interactions with landscapes or elements of nature". Consistent with the principles of our participatory method, we did not analyze the detrimental effects of nature on people because they were not brought to the discussion by stakeholders.

The participatory process involved 35 stakeholders from nine groups: tourism professionals (12), other professionals (2), students (3), farmers and other agricultural stakeholders (2), representatives of local and regional institutions (4), local elected representatives (3), representatives of nature conservation organizations (4), regional experts (expertise in natural risks, agriculture, climate, and tourism) (4), and second-home owners (1) (see description in Table A1.2 in Appendix 1). We considered as stakeholders the individuals that live or work in the case study area. Voluntary participants were invited from a list of stakeholders involved in previous studies (Lamarque et al. 2011, Lavorel et al. 2019, Bally et al. 2020), complemented with respondents from a questionnaire-based stakeholder analysis, snowball sampling, and open invitations disseminated to local municipalities and tourism offices.

We implemented a three-phase participatory process to capture perceptions of NCP and natural and human factors involved in their production. First, two workshops were organized, separating local stakeholders (nine people, one half-day) and regional experts ( 11 people, one full day) to facilitate free speech and avoid power issues. Then, 12 semistructured interviews (1-2 $\mathrm{h}$ each) were conducted with additional stakeholders selected for their knowledge and experience of local issues. A final feedback workshop was organized during a half-day with seven local stakeholders (including five who had already participated). During the first two workshops, participants were encouraged:
(1) to identify nature's contributions to local quality of life and to economic activities in the area; (2) to reflect on the factors directly or indirectly driving human-nature interactions that lead to NCP, such as social organization, policies, knowledge and technologies, land use, or natural drivers; and (3) to reflect on specific local issues linked to these interactions. During the first workshop, we suggested that participants frame their interactions with nature along three main quality of life dimensions (habitability, attractiveness, and rurality, as described below) rather than specific indicators of human well-being. These dimensions were confirmed and approved at the start of the second workshop. During postworkshop interviews, to complement data on these three main dimensions of quality of life and on related human-nature interactions, informants were questioned about the benefits, beneficiaries, and influencing factors of their activities in relation to nature. During the final workshop, we presented our understanding of the socialecological system and highlighted the main NCP and the natural and human factors related to the three dimensions of quality of life. Participants were invited to correct, discuss, or complete the proposed representation.

\section{Data analysis}

First, workshop and interview materials were analyzed using a deductive approach and classified according to the six IPBES framework components (Fig. 2) and according to the IPBES NCP classification. This first analysis led to separating the descriptions of human-nature interactions according to three dimensions of quality of life that stakeholders considered important. Stakeholders referred to nature in different terms, including land uses, ecosystems, and landscape units. We grouped them into 10 elements: five agricultural (summer pastures, hay meadows, larch meadows, grazed terraces, croplands), three natural (waterbodies, forests, scrublands), and two abiotic (built-up areas, rocks and ice; Table A1.1 in Appendix 1). 
Fig. 2. Intergovernmental Platform on Biodiversity and Ecosystem Services conceptual framework revisited from Diaz et al. (2015), including the three types of coproduction. Boxes represent the social-ecological system components, and numbered arrows represent their relationships (arrow numbers are the same as in Diaz et al. 2015).

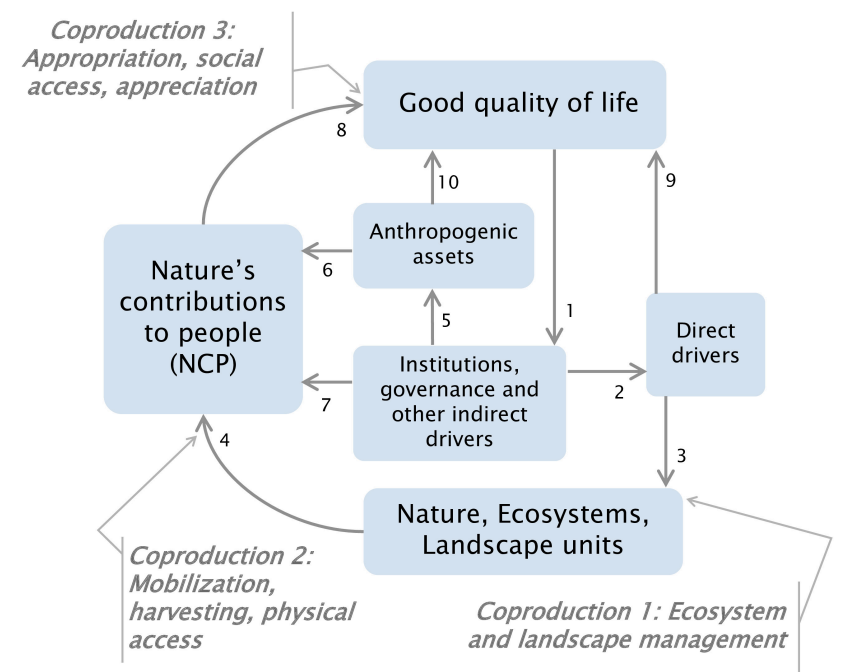

Second, we built from our data a matrix of benefit flows, i.e., the contributions of each landscape unit to NCP and of each NCP to the dimensions of quality of life, by assigning a score between 0 and 3 , based on the strength of each contribution revealed by discussions among stakeholders. This matrix was used to draw a Sankey diagram using the networkD3 function in R (Gandrud et al. 2016). The diagram shows the flows from landscape units to NCP and from NCP to quality of life (Fig. 3).

To address the limitations of the IPBES framework for analyzing coproduction, we complemented it with three types of coproduction in the NCP flow based on existing literature (Haines-Young and Potschin 2010, Schneider and Rist 2014, Spangenberg et al. 2014, Fedele et al. 2017, Lavorel et al. 2019). First, coproduction type 1 (CP1) acts at the level of ecosystem and landscape management (arrow 3 in Fig. 2) and includes intentional (or sometimes unintentional) changes in the ecosystem to obtain benefits such as fertilization for fodder production or planting protection forests to reduce disaster risk. Coproduction type 2 (CP2) encompasses the mobilization, harvesting, and physical access needed to obtain NCP (arrow 4 in Fig. 2), such as harvesting natural products, mowing pastures, visiting a scenic place, or building infrastructure for water transportation. Coproduction type 3 (CP3) is related to how NCP benefits people's well-being through appropriation, appreciation, and social access (arrow 8 in Fig. 2), such as enjoying a beautiful landscape, buying dairy products, enriching one's identity based on natural elements, or recognizing protection against risk. The IPBES framework and the NCP coproduction types were applied for analyzing the data collected from stakeholders.
Lastly, to characterize the three types of coproduction mechanisms, we first determined the coproduction actions based on the nature-related activities identified by participants (CP1-3 actions in Fig. 3). Only coproduction actions perceived by stakeholders were considered. Some flows take place without recognized coproduction actions, either because they have not been identified by participants or because the benefits do not require human actions. We then described the four forms of human-derived capital (Jones et al. 2016, Palomo et al. 2016) involved in the coproduction actions of each NCP (K in Fig. 3). Therein, we specified human-derived capital considered in the IPBES conceptual framework as anthropogenic assets and institutions and governance. Human capital refers to the productive capacity of individuals and is characterized by people's knowledge, skills, education, and health status as well as motivations, beliefs, and behavioral habits. Social capital consists of all the social relations available to a person associated with the formal and informal networks, trust, shared values, and norms required to improve societal interactions in and between groups of individuals. Manufactured capital comprises physical assets such as roads, vehicles, buildings, machinery, tools, seeds, etc. that support the production process of goods and services. Financial capital includes money, savings, credits, and subsidies that enable interactions between other forms of capital necessary for the production, management, or improvement of NCP. We assigned capital to coproduction actions based not only on the factors identified by the participants but also on our knowledge of the social-ecological system. We then classified them into the four types of capital.

\section{RESULTS}

We use a Sankey diagram to summarize the links between nature or landscape units, NCP, and quality of life perceived by stakeholders as a representation of stakeholders' understanding of the social-ecological system (Fig. 4). Here, we first describe the three aggregate quality of life dimensions emerging from our analysis (right side of Fig. 4), followed by groups of NCP associated with each of them (center of Fig. 4). We then focus on NCP contributions to quality of life and the contributions of nature or landscape units to these NCP (left side of Fig. 4), and end with the description of mechanisms and human-derived capital associated with each of the three coproduction types.

\section{Dimensions of good quality of life}

Stakeholders structured their descriptions of the mountain socialecological system and human-nature interactions around three quality of life dimensions that are associated with archetypes of local livelihoods or ways of life (i.e., typical patterns by which all local livelihoods or ways of life are represented or combined). Even though these three dimensions were used as an analytical lens to separate parts of the social-ecological systems, we recognize that they are connected (i.e., one dimension may affect another in the life of a stakeholder) and mixed (i.e., the quality of life of a local stakeholder often combines the three dimensions).

The "rurality" dimension was linked to the maintenance of traditional agricultural practices (mowing and grazing) and rural life in the region (Fig. 4). According to stakeholders, rural life and dynamics that maintain open landscapes depend on farm 
Fig. 3. Nature's contributions to people (NCP) coproduction framework showing how coproduction acts on the flows of benefits from nature to quality of life through NCP (gray arrows). The flow may require (although not always) human interventions as coproduction actions (CP1-3 actions), which depend on the availability of capital (K). Although not examined in our study, there are feedback loops from quality of life to coproduction actions.

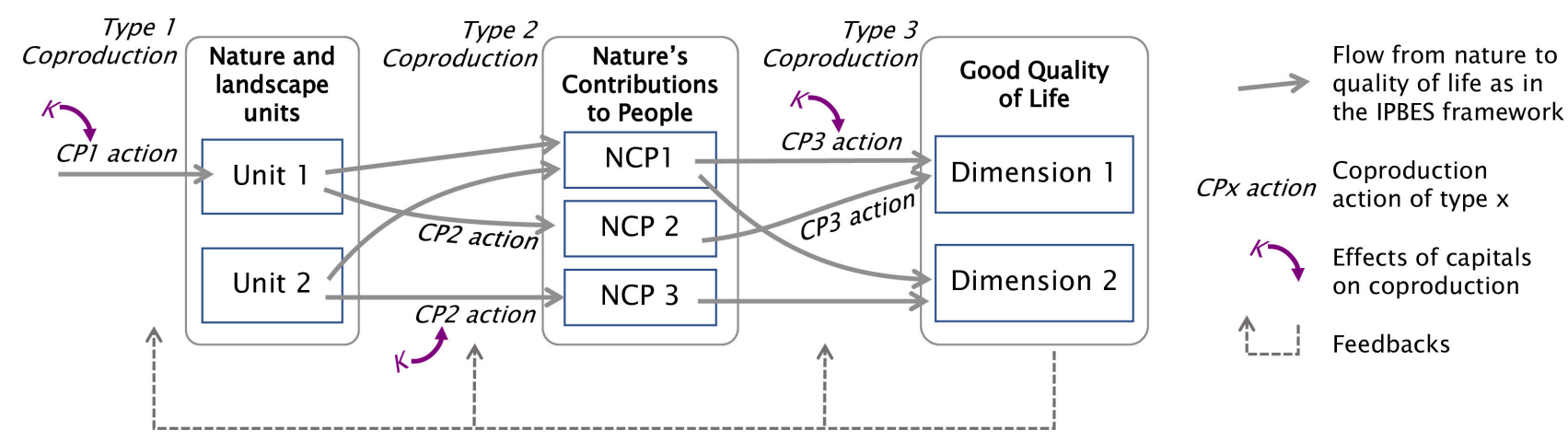

livelihood with a critical role of off-farm jobs to maintain income during winter. Stakeholders welcomed the settlement of new farmers but were concerned that they may stop traditional mowing practices because of their higher costs compared with external fodder purchase.

I have helped new farmers settle in, but the problem is that they do not want to mow the land they have been allocated... so I am worried about the future of mowing and terraces... the decrease in mowing practices will have an impact on the environment and the quality of the flora. (Male farmer).

The "habitability" dimension in stakeholder discourses referred to how people construct a living space by interacting with nature and society through material or immaterial processes (Fig. 4). Thus, the wild landscape and natural and cultural heritage mostly linked to agriculture and mountain outdoor activities were cited as key elements of people's attachment to this region. Harsh climatic and topographical conditions were perceived as constraining but also as the origin of social cohesion.

In the enthusiasm for the region we find all the elements of nature that create attachment to it. (Male secondhome owner).

The "attractiveness" dimension was linked to the importance of tourism for the region, requiring this area to be attractive for visitors (Fig. 4). Landscape was presented by stakeholders as the support of this attractiveness because it is a major strength and a touristic resource of the area, with a wild aspect on north-facing slopes and managed grasslands on south-facing slopes. This dimension overlapped with the other two dimensions because of tourism's central role in the local economy, upon which most jobs depend and which sets the pace for all the local life.

\section{Nature's contributions to good quality of life}

Stakeholders perceived multiple contributions of nature to their daily life, economic activities, and good quality of life (Figs. 4 and
5; for a full description, see Table A1.3 in Appendix 1). The main NCP cited by the stakeholders were nonmaterial, including aesthetic enjoyment, experiences of nature (education, information, inspiration, self-development) in relation to tourism and leisure activities (healing, relaxation, recreation, leisure, tourism, aesthetic enjoyment), and a strong sense of place (religious, spiritual and social cohesion, sense of place, belonging linked to heritage of mountain culture, traditional dishes). Material NCP such as food and feed production (fodder, pasture, crops, food from domestic animals, feed for animals, plants, dairy products, honey, gardening) were also prominently cited. Stakeholders also mentioned regulating NCP such as regulation of hazards (floods, rock falls, avalanches, landslides, erosion), water and air quality (air depollution, water quality for drinking and for recreational activities in lakes and rivers), but mentioned them less frequently than other NCPs and did not always link them explicitly to ecological functions.

According to stakeholders, individual NCP contributed differently to the three dimensions of good quality of life (Fig. 4), forming bundles that sometimes included the same NCP. Rurality was understood as dependent mainly on material NCP of fodder production (quality, quantity, resilience), which supports heifer production at the core of the traditional agricultural economy, and, more anecdotally, primary production (meat, dairy, wool), which is enjoyed by both locals and visitors. Rurality was also associated with regulating NCP such as soil erosion reduction, water regulation, and nutrient cycling, which contribute directly to fodder quality and quantity and reduce production risks, for example, in case of droughts.

Stakeholders emphasized the contribution of nonmaterial NCP to both habitability and attractiveness due to the anchoring of local life in nature activities. Aesthetic enjoyment and all nature experiences such as outdoor recreational and leisure activities (hiking, climbing, walking, hunting, cycling, etc.) were shared by most locals and visitors. 
Fig. 4. Sankey diagram presenting the contributions of nature and landscape units to nature's contributions to people and to quality of life dimensions. Each quality of life dimension (rurality, attractiveness, and habitability) is associated with a color. The color of other boxes is a mix of the dimensions' colors, depending on how the element contributes to the three dimensions (for example, a reddish box contributes mostly to rurality). The triangle helps in visualizing the color mixes for each element. Coproduction actions perceived by stakeholders are shown in italics to the left of the boxes or on the links between boxes.

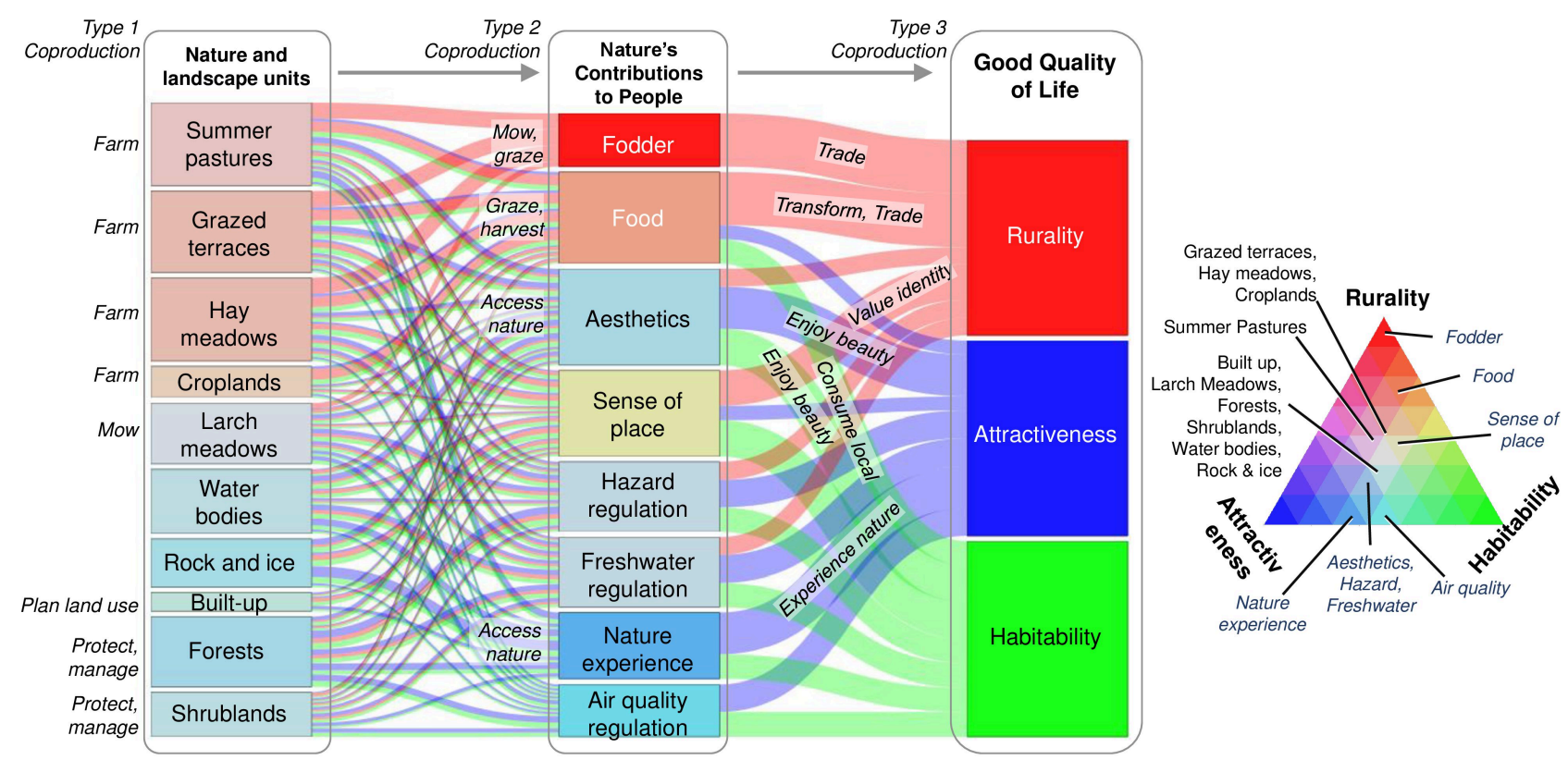

Here, it is a necessity to practice mountain activities; that's all there is to do here! We use the mountains for sport... and in search of wilderness. (Male teenager).

Stakeholders also highlighted the potential of the landscape for education and learning based on natural elements such as plants and animals that are key to attracting visitors to the national park. Alpine biodiversity has been used for a long time in traditional cuisine and is also part of the botanical garden collection. Finally, mountain ecosystems enhance spirituality, art creation, and emotional experiences, according to stakeholders.

It is a grandiose landscape, romantic, with incredible nature. There is a mystical character to the place. As you can see, there is a rich cultural and religious heritage, such as the contemporary music festival located here. (Male second-home owner).

In addition, regulating NCP were also considered important regarding habitability and attractiveness because water and air quality regulation contribute to enjoyment of nature and are valuable to locals and visitors. As in all mountain areas, regulation of hazards and extreme events was recognized by stakeholders as a critical NCP for reducing the vulnerability of people and infrastructure.

Sense of place was highly prominent in discourses and, according to stakeholders, contributed to the three dimensions of good quality of life. Indeed, they related sense of place both to the maintenance of traditional agricultural practices as a heritage factor and to the creation of a strong local identity, which is a strong motivation for long-term and new residents to live as and where they live and is appreciated by visitors.

The local identity is strongly linked to the environment, especially to the agricultural practices that maintain this open and unique landscape. (Female hotel keeper).

Landscape units producing nature's contributions to people Stakeholders reported that all landscape units contributed to the three dimensions of good quality of life through NCP, albeit to different extents. The contribution of landscape units to habitability was similar to their contribution to attractiveness, given that locals and tourists benefit from landscapes in a similar manner (Fig. 4, triangle shows that most landscape units are equidistant from the habitability and attractiveness vertices). Two clusters of landscape units can be distinguished according to their contributions to rurality (Fig. 4): one cluster with higher contributions prevailing on south-facing slopes and at the valley bottom (grazed terraces, hay meadows, croplands, and summer pastures), and the other cluster with lower contributions prevailing on north-facing slopes (larch meadows, forests, shrublands, water bodies, rocks and ice, and built-up areas). Indeed, stakeholders perceived that agricultural ecosystems do not only contribute to material NCP but also to nonmaterial NCP such as aesthetics and sense of place. Nevertheless, the two clusters are close to each other and in the center of the colored triangle (Fig. 4). Thus, individual landscape elements contribute to a mix of dimensions of good quality of life, which reveals the multifunctionality of the landscape. This multifunctionality is not only the result of the diversity of landscape units (Fig. 1), it also occurs within each landscape element. 
Fig. 5. Contribution of nature's contributions to people (NCP) to the three dimensions of good quality of life, according to stakeholders' perceptions. The size of the circle indicates the strength of the contribution, from low (small circle) to high (large circle); blank = not mentioned.

\begin{tabular}{|c|c|c|c|c|c|c|c|c|}
\hline & \multicolumn{8}{|c|}{ NCP } \\
\hline & $\begin{array}{l}\text { Aesthetic } \\
\text { enjoyment }\end{array}$ & $\begin{array}{c}\text { Nature } \\
\text { experience }\end{array}$ & $\begin{array}{l}\text { Sense of } \\
\text { place }\end{array}$ & $\begin{array}{c}\text { Fodder } \\
\text { production }\end{array}$ & $\begin{array}{c}\text { Food } \\
\text { production }\end{array}$ & $\begin{array}{c}\text { Hazard } \\
\text { regulation }\end{array}$ & $\begin{array}{l}\text { Fresh } \\
\text { water }\end{array}$ & $\begin{array}{l}\text { Air quality } \\
\text { regulation }\end{array}$ \\
\hline Rurality & $\bullet$ & & & & & $\bullet$ & $\bullet$ & \\
\hline Habitability & & & & & & & & \\
\hline Attractiveness & & & & & • & & & \\
\hline
\end{tabular}

Lastly, the built-up areas and rocks and ice landscape units, which are not biotic elements, were considered by stakeholders to be involved in NCP coproduction. For example, all landscape units, including rocks, ice, and traditional villages and hamlets were seen to contribute to aesthetic enjoyment and nature experiences, and above all, to sense of place.

\section{Nature's contributions to people coproduction in the social- ecological system}

The coproduction mechanisms of ecosystem management (CP1), associated with maintaining rurality, encompass agricultural practices such as the management of hay meadows, pastures, mountain pastures, as well as crops for food and feed production. For example, plowing and sowing fields and organic fertilization with manure from winter stables are important practices. Agricultural practices also contribute to the sense of place within NCP by maintaining traditional practices and landscapes. Grassland and crop primary production, mostly fodder and potatoes, are then mobilized (CP2) through mowing, grazing by transhumant herds, or crop harvests. Finally, the benefits of NCP are appropriated (CP3) through product transformation, selling, or consumption, thus contributing to the maintenance of agricultural activity and practices and also to the satisfaction of local needs and other quality of life dimensions. For example, the main source of income is from selling heifers for Beaufort cheese production in the adjacent Maurienne Valley or from processing animal products for cheese, meat, and wool marketed locally.

The coproduction chains linked to habitability and attractiveness depend on the same mechanisms because they involve the same NCP (shown in mixes of blue and green in Fig. 4). First, the management of all landscape units is involved in this coproduction chain. Indeed, by shaping the landscape, agricultural practices and preservation of natural areas by Ecrins National Park are a first step (CP1) that participates in all the NCP involved, such as aesthetics and nature experiences. Second, these NCP are mainly mobilized through access to ecosystems (CP2) with the development and maintenance of access and infrastructure such as roads, footpaths, or information signs. Visitors and locals shared the same access to nature and infrastructure (roads or paths), although it was more important for attractiveness for tourism. Finally, there are similarities between habitability and attractiveness regarding the appropriation of products (CP3); for example, both locals and tourists appreciate local food and water quality. The same overlap applies to the appreciation (CP3) of benefits associated with the experience of nature as regards mountain sports and landscape aesthetics because tourists and many inhabitants alike have chosen this region for its proximity to nature and mountain activities. However, appreciation and creation of local identity (CP3) differ significantly between habitability and attractiveness and are shared mainly between habitability and rurality. We note that while we presented coproduction processes separately for rurality vs. attractiveness and habitability, ecosystems managed for rurality also contribute to attractiveness and habitability, in particular, by contributing to the landscape aesthetics and sense of place that are important for inhabitants and tourists.

Lastly, for regulating NCP, stakeholders' discourses referred to only one CP1 mechanism with the establishment of slopeprotection forests to regulate avalanche risks. Overall regulating NCP were not mobilized or appreciated by locals; that is, participants acknowledged risks but did not make the link with ecosystem contributions.

\section{Human-derived capital involved in nature's contributions to people coproduction}

Different types of human-derived capital are involved in managing, mobilizing, and appreciating the benefits of various NCP within the three coproduction chains (Fig. 6; Table A1.4 in Appendix 1). For material NCP, the different types of agricultural management and production $(\mathrm{CP} 1$ and $\mathrm{CP} 2)$ required similar types of human-derived capital. Such capital includes: infrastructure (farm buildings), accessibility (roads), machinery, animals, and seeds (manufactured capital); labor, knowledge, and skills related to farming (human capital); and agricultural subsidies and personal financial inputs (financial capital). Finally, transformation and trading of products (CP3) depend on the same types of capital, mainly infrastructure (processing units, storage; manufactured capital), supply chains and markets (financial capital), and also on knowledge about transformation and marketing (human capital). These activities are also highly 
Fig. 6. Categories of human capital involved in the three types of coproduction of individual nature's contributions to people.

\begin{tabular}{|c|c|c|c|c|c|}
\hline $\begin{array}{l}\text { Nature's } \\
\text { contributions } \\
\text { to people }\end{array}$ & $\begin{array}{l}\text { Nature } \\
\text { and } \\
\text { landscape } \\
\text { units }\end{array}$ & $\begin{array}{l}\text { Quality of life } \\
\text { dimensions }\end{array}$ & Type 1 coproduction & Type 2 coproduction & Type 3 coproduction \\
\hline \multirow[t]{2}{*}{$\begin{array}{l}\text { Fodder and } \\
\text { food } \\
\text { production }\end{array}$} & \multirow[t]{2}{*}{$\begin{array}{l}\text { All } \\
\text { agriculture } \\
\text { lands }\end{array}$} & Rurality & $\begin{array}{l}\text { Farming and cropping } \\
\text { practices }\end{array}$ & $\begin{array}{l}\text { Harvesting resources } \\
\text { (grazing, mowing...) } \\
\text { of o } 1 \text { III }\end{array}$ & $\begin{array}{l}\text { Transforming and } \\
\text { trading products } \\
\end{array}$ \\
\hline & & $\begin{array}{l}\text { Habitability, } \\
\text { attractiveness }\end{array}$ & None & None & $\begin{array}{l}\text { Consuming products } \\
\text { A }\end{array}$ \\
\hline \multirow[t]{2}{*}{$\begin{array}{l}\text { Aesthetic } \\
\text { enjoyment }\end{array}$} & \multirow[t]{2}{*}{ Landscape } & Rurality & $\begin{array}{l}\text { None directly (results } \\
\text { from farming) }\end{array}$ & None & None \\
\hline & & $\begin{array}{l}\text { Habitability, } \\
\text { attractiveness }\end{array}$ & Conserving nature & $\begin{array}{l}\text { Accessing landscape } \\
+4 \text { (9) }\end{array}$ & $\begin{array}{c}\text { Enjoying beauty } \\
\text { A }\end{array}$ \\
\hline $\begin{array}{l}\text { Nature } \\
\text { experiences, } \\
\text { learning \& } \\
\text { inspiration }\end{array}$ & Landscape & $\begin{array}{l}\text { Habitability, } \\
\text { attractiveness }\end{array}$ & $\Delta$ & $\because$ & Experiencing nature \\
\hline $\begin{array}{l}\text { Sense of } \\
\text { place, } \\
\text { identity }\end{array}$ & Landscape & $\begin{array}{l}\text { Habitability } \\
\text { Rurality }\end{array}$ & $\begin{array}{l}\text { None directly (results } \\
\text { from farming) }\end{array}$ & None & $\begin{array}{c}\text { Enjoying local identity } \\
\text { (I) }\end{array}$ \\
\hline $\begin{array}{l}\text { Regulation of } \\
\text { hazards and } \\
\text { extreme } \\
\text { events }\end{array}$ & Forest & $\begin{array}{l}\text { All } \\
\text { dimensions }\end{array}$ & $\begin{array}{l}\text { Managing protection } \\
\text { forests }\end{array}$ & None & None \\
\hline $\begin{array}{l}\text { Regulation of } \\
\text { freshwater }\end{array}$ & Landscape & $\begin{array}{l}\text { All } \\
\text { dimensions }\end{array}$ & None & $\begin{array}{l}\text { Bringing water to } \\
\text { different users } \\
\text { :0̈: IIII }\end{array}$ & Consuming water \\
\hline $\begin{array}{l}\text { Air and soil } \\
\text { quality }\end{array}$ & Landscape & $\begin{array}{l}\text { All } \\
\text { dimensions }\end{array}$ & None & None & None \\
\hline
\end{tabular}

\begin{tabular}{|c|c|c|c|c|}
\hline \multicolumn{2}{|c|}{ Manufactured capital } & Financial capital & Human capital & Social capital \\
\hline$£$ & $\begin{array}{l}\text { Public } \\
\text { infrastructure }\end{array}$ & $\begin{array}{l}\text { Subsidies and } \\
\text { public funding }\end{array}$ & Labor & $\begin{array}{l}\text { Regional to national } \\
\text { institutions, public policies }\end{array}$ \\
\hline & Private goods & $\begin{array}{l}\text { Trade and } \\
\text { markets }\end{array}$ & $\begin{array}{l}\text { Knowledge } \\
\text { and skills }\end{array}$ & $\begin{array}{l}\text { Local institutions and } \\
\text { networks }\end{array}$ \\
\hline 4 & Living assets & $\begin{array}{l}\text { Incomes and } \\
\text { savings }\end{array}$ & $\begin{array}{l}\text { Preferences } \\
\text { and values }\end{array}$ & Access and tenure rules \\
\hline
\end{tabular}

dependent on institutions and governance related to agriculture (social capital), particularly land tenure and allocation, and also on the support of local and regional institutions and networks linked to farming, such as the regional office for agriculture or the transhumance network (social capital). The coproduction chain of material NCP to attractiveness and habitability also includes the consumption of products (CP3), which is highly dependent on preferences and values associated with local products (human capital) in addition to retail infrastructure (manufactured capital) and individual financial resources for buying products.

For nonmaterial NCP such as aesthetic enjoyment and nature experiences, human-derived capital requirements are lower than 
for material NCP. Nature conservation (CP1) requires mainly knowledge and skills (human capital), public funding (financial capital), and above all, conservation policies and rules such as the enforcement of National Park regulations (social capital). Nature access (CP2) for these NCP requires access and information infrastructure (manufactured capital), access rules (social capital), and collective and individual financial capital. As for the enjoyment of landscape beauty and physical and psychological activities (CP3), coproduction depends mainly on preferences and values (human capital), as well as sports equipment (manufactured capital), practitioners' experience (human capital), and individual purchasing power (financial capital). Sense of place benefits from all of these coproduction processes, particularly agricultural activities, but is strictly dependent on values and preferences (human capital) that allow residents to appreciate and create local identity.

Regarding regulating NCP, we observed limited coproduction because few types of human-derived capital were involved in their benefits. It should be noted that the establishment of protection forests (CP1) requires access infrastructure (manufactured capital) as well as a public financing system (financial capital), knowledge about natural risks (human capital), and strong legislation (social capital). Water consumption is also regulated by abstraction rights (social capital) and access through piping infrastructure (manufactured capital).

\section{DISCUSSION}

\section{Operationalization of the Intergovernmental Platform on Biodiversity and Ecosystem Services framework and coproduction lens}

We used the IPBES framework both in the design of the participatory process and as an analytical tool to identify the components of the site's social-ecological system. Our experience highlights some strengths and weaknesses of the framework for understanding local NCP coproduction. The IPBES framework appears to be sufficiently adaptable for this local implementation. During the whole process, many representations of nature, human-nature interactions, and quality of life were expressed by participants, and also by scientists during the analysis. This framework is sufficiently comprehensive to cover such representations and values as well as all elements mentioned by participants about social-ecological interactions. By using the concept of NCP and quality of life, we were able to capture different types of values associated with nature, such as the recognition of: the intrinsic value of nature through its protection; its instrumental value in its perception as a resource for exploitation; and above all, its relational values that reflect the relationship between people and nature (Pascual et al. 2017). Indeed, the dimensions of quality of life are the result of how inhabitants perceived their relationships with nature. In addition, the NCP concept proved easy to use with stakeholders, particularly because it relates directly to quality of life and to concrete interactions with nature in people's lives rather than imposing the more rigid framing of ecosystem services (Bieling et al. 2014, Kadykalo et al. 2019).

Divergences appeared between participants and scientists in their framing of social-ecological systems. Regarding good quality of life, we structured the analysis around the three aggregated dimensions proposed by participants (habitability, attractiveness, and rurality), instead of using the existing frameworks of human well-being or happiness (e.g., Maslow 1943, Ryan and Deci 2001). These three dimensions match the three bundles of NCP identified previously in the same region as three archetypes of landscape perception, respectively, "heritage", "postcard", and "grass" (Quétier et al. 2010), and are generally consistent with findings in other European cultural landscapes (e.g., IniestaArandia et al. 2014, Plieninger et al. 2019, Zoderer et al. 2019). Regarding the nature component of the IPBES framework, stakeholders had difficulty specifying spontaneously the natural features contributing to their quality of life (such as ecosystem elements or properties) and found it easier to relate to landscape units (Bieling et al. 2014).

In line with previous analyzes of stakeholders' free descriptions of their relations to a landscape (Quétier et al. 2010, Bieling et al. 2014), we chose to focus on the NCP perceived by the participants to capture local knowledge, which is still insufficiently recognized in social-ecological system analyses (Mastrángelo et al. 2019). Many previous participatory studies have instead presented a definition of ecosystem services to participants or proposed predefined lists of ecosystem services for discussion (Lamarque et al. 2011, Palomo and Montes 2011, Haida et al. 2016, Zoderer et al. 2019). Although the former unconstrained methods may fail to uncover implicit contributions, and especially, regulating contributions, the latter may bias responses. Participatory mapping may provide a more sophisticated method for eliciting spontaneous local NCP knowledge by fostering deliberation and learning among participants (García-Nieto et al. 2019). The short duration of our workshops, however, did not allow for this approach.

One other difficulty came from our focus (and that of IPBES) on nature's contributions to good quality of life, whereas participants mentioned many anthropogenic assets that contributed to good quality of life without relating to nature (arrow 10 in Fig. 2). For example, public services and infrastructure (schools, hospitals, roads) are essential to quality of life and play a key role in socialecological systems but are overlooked in our analysis and in IPBES, which explicitly states that this link is among the "links that are acknowledged as important, but are not the main focus" (Díaz et al. 2015:5). These links were often discussed by stakeholders, but their analysis was beyond our scope. This observation emphasizes the challenge of giving the right level of attention to non-nature contributions to quality of life in a socialecological system analysis (Sarkki 2017).

Nevertheless, the IPBES framework presents some limitations. For example, it was not tailored for analyzing multiple NCP and their interactions as NCP bundles. Here, the analysis of NCP through the three dimensions of quality of life allowed us to focus on bundles and to reveal the consistency between these NCP bundles in terms of coproduction inputs. Finally, our study strengthened the consideration of NCP coproduction in the IPBES framework. Benefiting from previous work on coproduction (Spangenberg et al. 2014, Jones et al. 2016, Palomo et al. 2016, Fedele et al. 2017), we demonstrated that coproduction occurs not only between nature and anthropogenic assets (arrow 6 in Fig. 2). Rather, we refined the framework by distinguishing three coproduction types at different steps of NCP, thereby 
clarifying the role of humans ("anthropogenic assets" and "institutions and governance") within each of arrows 3,4 , and 8 in Fig. 2.

\section{Differing intensities of coproduction among nature's} contributions to people categories and across coproduction types There is still limited knowledge about how anthropogenic factors influence multiple mountain NCP linked to human quality of life (Mengist et al. 2020). Here, by examining human inputs for coproducing NCP, we discovered that participants were more able to identify and describe NCP with a higher level of coproduction and with more human-derived capital input. This ability increased the relative emphasis on material vs. nonmaterial and regulating $\mathrm{NCP}$ as compared with earlier list-based ecosystem services (Lamarque et al. 2011). Indeed, mechanisms of management (CP1) and mobilization (CP2), especially of agricultural NCP, were familiar and well structured in stakeholders' discourses. Conversely, stakeholders found greater difficulties in articulating their views on the coproduction of nonmaterial NCP and even less of regulating NCP, which is predominantly of type 3 (Fig. 6).

More generally, consistent with Palomo et al. (2016) and Outeiro et al. (2017), we observed a quantitative gradient of humanderived capital from NCP with intense coproduction, mainly material (such as food) to NCP with limited human involvement (such as air quality or water regulation) (Fig. 6). Additionally, our analyses revealed that the types of capital differed qualitatively between coproduction types and between material, nonmaterial, and regulating NCP.

First, multiple types of human-derived capital are needed for some NCP such as material NCP produced by agricultural practices (Vialatte et al. 2019), which also strongly depend on natural capital even if that was often not mentioned by participants. Farming (CP1), harvesting and mowing (CP2), and transforming and trading (CP3) require knowledge, skills, infrastructure, tools, and labor and also strongly depend on individual investments and subsidies. These practices are also highly structured by institutions and rules, whether formal or informal (Schermer et al. 2016).

Second, coproduction of some NCP depends mostly on intangible capital such as social, human, and financial capital. For example, nature conservation (CP1; i.e., establishment of a national park and other conservation measures) underpins the coproduction of many nonmaterial and regulating NCP. It is strongly driven by multiple forms of human-derived capital such as knowledge, skills, and especially, preferences and motivations, and largely depends on social and financial capital governed by formal rules and institutions (Ban et al. 2013).

Additionally, physical access to nature is a prerequisite for the coproduction of nonmaterial NCP. Access depends heavily on social capital through planning instruments and land tenure or access rules, as well as on infrastructure such as paths and signage. However, nonmaterial NCP also sometimes require input of other types of capital, particularly for the physical experiences of nature, including sports and leisure activities (i.e., equipment, financial resources, and knowledge of and skills around particular practices to enjoy nature).

Conversely, some NCP are predominantly produced by natural capital, with limited human-derived capital input. For nonmaterial NCP, appropriation, social access, appreciation (CP3) of aesthetics, psychological experiences, and sense of place mobilize a single form of human-derived capital, values, and preferences (human capital) and are highly dependent on natural capital. Assessing such coproduction is challenging (Daniel et al. 2012, Hernández-Morcillo et al. 2013, Bieling et al. 2014) and more complex to describe than for other NCP because people perceive, appreciate, and value nature in diverse ways (Pascual et al. 2017, Raymond et al. 2018).

Regulating NCP entail very limited coproduction at the study site. Participants did not perceive the regulation of risks, water quality, or air quality as nature benefits, with the exception of a forest planted for avalanche and landslide protection. Regulating NCP are not considered as being coproduced because they are linked to ecological functions that directly benefit quality of life and do not require human inputs (Spangenberg et al. 2014, Locatelli et al. 2017). Nevertheless, while regulating NCP are not perceived as managed or coproduced, they definitely contribute to the three quality of life dimensions and are often a cobenefit or a trade-off within coproduction of other NCP, thus representing intermediate services (Felipe-Lucia et al. 2015). This lack of recognition of regulating services can be alleviated with predefined NCP lists. Using this method, Zoderer et al. (2019) showed that regulating ecosystem services were considered more important than provisioning and cultural services in three types of mountain landscapes. Participatory mapping with mixed groups of local stakeholders and experts has also enabled learning and has resulted in increased recognition of regulating services (García-Nieto et al. 2019). The lack of perception of some NCP nevertheless raises the question of the limited knowledge of local actors about the NCP from which they benefit. This result also highlights the need to combine different methods and sources of stakeholder, expert, and scientist knowledge to gain better understanding of tangible and intangible coproduction inputs, either measured or perceived (Reyers et al. 2013).

\section{Role of coproduction for nature's contributions to people synergies and trade-offs}

Our qualitative, analytical approach of examining three coproduction types and the associated categories of humanderived capital for multiple NCP and multiple contributions to quality of life allowed us to show how NCP coproduction creates social-ecological trade-offs and synergies between multiple NCP (Lavorel et al. 2020). While synergies and trade-offs among NCP have become a central theme (Crouzat et al. 2015, Saidi and Spray 2018), recent studies of coproduction have rather analyzed single NCP independent of each other (Jones et al. 2016).

Multifunctionality can be analyzed at two different scales, landuse type and landscape (Lavorel et al. 2017). Here, most land uses produce multiple NCP and contribute to multiple dimensions of quality of life, and the landscape mosaic reinforces the diversity of NCP and contributions to quality of life (Fig. 4). By focusing on coproduction, we show that, in addition to biophysical mechanisms at parcel and landscape scales (Lavorel et al. 2017), different types of coproduction underpin synergies and trade-offs between NCP.

First, type 1 coproduction plays a key role for bundles of NCP. Indeed, agricultural land management and natural area protection are critical for the entire benefit flow and quality of life dimensions. Ecosystem management is a key driver for trade- 
offs among ecosystem services (Bennett et al. 2009) and has been the main focus of previous analyses of multifunctionality in this and other mountain social-ecological systems (Temperli et al. 2012, Grêt-Regamey et al. 2013, Lavorel et al. 2017). Potential changes in ecosystem management (CP1) will affect other types of coproduction and their benefits (Torralba et al. 2018), for example, the possibility of appreciating (CP3) the aesthetic value or the sense of place provided by a landscape with agricultural terraces or a nature experience offered by protected natural areas. Even if agricultural management is initially motivated by maintenance of rurality, it coproduces nonmaterial NCP that are at the heart of habitability and attractiveness. Conversely, protected natural areas can generate trade-offs among all types of NCP coproduction by excluding other forms of management (CP1), limiting access (CP2), and favoring certain recreational activities (CP3).

Second, physical access (type 2 coproduction) that is critical for all dimensions of quality of life in mountain rural and touristic places can also create synergies by facilitating landscape access for other types of coproduction. For example, creating tracks to access agricultural parcels (CP1) allows appropriation or appreciation of the rural landscape (CP3). However, trade-offs can also occur depending on access rules, which, by excluding some beneficiaries, may create conflicts.

Finally, type 3 coproduction could be less subject to trade-offs because of the high level of intangible human capital involved, such as preferences and values. It may still create trade-offs with ecosystem management (CP1) when it is inconsistent with values of local communities or visitors. For example, new demands for local products such as vegetables, fruit, or dairy products could be in conflict with the current management of agricultural land because of the strong inertia of traditional heifer breeding, which preempts available farmland.

In our study, different coproduction mechanisms led to NCP synergies, rather than trade-offs, because of the strong interlinkages between the three dimensions of quality of life. This result may reflect the fact that many actors share interests regarding quality of life and that many people or households are simultaneously residents (and are thus concerned by habitability), farmers (rurality), and tourism professionals (attractiveness). It may also reflect limited conflicts in the use of natural resources among the three dimensions of quality of life. This result is well illustrated by the example of agricultural NCP coproduction benefiting the three quality of life dimensions (Fig. 4). However, this observation is not generalizable: A study in marine fisheries concluded that human coproduction of NCP at the ecosystem level (CP1) led to trade-offs among beneficiaries and that high anthropogenic inputs in coproduction reduced opportunities for synergies and cobeneficiaries (Outeiro et al. 2017).

\section{Implications of nature's contributions to people coproduction for coproducers}

By identifying stakeholders involved in NCP coproduction and their interactions, coproduction analysis can highlight synergies or conflicts between stakeholders, whether they are direct or indirect beneficiaries. However, here, we only report aggregated results across participants and do not distinguish perceptions across social groups (Barnaud et al. 2018, Zoderer et al. 2019).
First, different actors are involved in the three types of coproduction, which reveals possible coordination gaps at the landscape level. For instance, the landscape is managed by farmers, municipalities, and the National Park, but not by other main NCP beneficiaries and main economic actors in the region such as visitors, inhabitants, and tourism professionals. The fact that landscape managers and beneficiaries are not the same people and that ecosystem interventions for coproduction (CP1, CP2) ripple through the entire coproduction chain means that NCP beneficiaries depend on landscape managers (Felipe-Lucia et al. 2015, Vallet et al. 2019).

Second, there are feedback loops from quality of life and people's perception of it to coproduction actions at different levels. For example, the loss of agricultural incomes following changes in market demand may incentivize farmers to modify how they farm (CP1), what crops they harvest (CP2), and what products they transform and sell (CP3). Changes in one type of coproduction also influence other types of coproduction. In the same example of farmers changing their production, adjustments in marketing (CP3), driven by changes in preferences or consumption habits, affect the entire coproduction chain (CP1/CP2 and CP3) by changing the values assigned to $\mathrm{NCP}$ and landscape units (Dendoncker et al. 2018, Ellis et al. 2019). In addition, feedbacks also influence the multifunctionality of the landscape because of synergies among NCP or coproduction (Lavorel et al. 2020). For example, because place attachment by residents, agricultural activities by farmers, and landscape contemplation by tourists all rely on the maintenance of an open agricultural landscape, the perception of the three dimensions of quality of life supports similar coproduction activities. Cooperation between managers and beneficiaries, and more broadly, between coproducers through landscape-level collective action, thus appears critical (Barnaud et al. 2018). Hence, NCP coproduction analysis can highlight existing collaborations for sharing different types of capital or facilitating access to them.

Third, rules and power regulate access to most types of capital needed for coproduction. NCP coproduction is subject to inequalities in access to different types of capital, which can lead either to conflict or to collaboration (Vallet et al. 2019). To coproduce NCP, managers and beneficiaries need to have access to natural capital, as well as knowledge, financial assets, infrastructure, and public support. Coproduction analyses thus not only need to consider physical and social access as mechanisms of $\mathrm{CP} 2$ and $\mathrm{CP} 3$, but also heterogeneity in access to capital across beneficiaries among all coproduction types (Berbés-Blázquez et al. 2017). Consequently, indirect factors, particularly those related to governance and social organization around the management and distribution of NCP, need to be considered for analyzing coproduction (Martín-López et al. 2019). We observed that in stakeholders' narratives, coproduction was often strongly linked to indirect drivers (especially policies and markets), upon which they have little agency. Agency for coproduction thus depends on which types of capital are under the control of coproducers (Felipe-Lucia et al. 2015).

\section{CONCLUSION}

In this study, we propose an operationalization of the IPBES conceptual framework through a participatory approach combining quality of life dimensions and an analysis of NCP 
coproduction that provides an integrated view of social-ecological functioning. Our analyses demonstrate that the IPBES framework is a good support for describing the functioning of a social-ecological system by integrating all the drivers related to the human-nature interactions perceived by stakeholders. Moreover, we suggest that using quality of life as a catalyst for discussion around human-nature interactions can overcome difficulties associated with the concept of ecosystem services by allowing stakeholders to relate to concrete and meaningful experiential elements.

However, applications of the IPBES framework should put more emphasis on NCP coproduction. Coproduction analysis underlines the crucial importance of agency by providing a better understanding of the contribution of different types of humanderived capital to the production of benefits from nature, which is still understudied. This approach will constitute a step forward in assessing the contributions of socioeconomic, institutional, human, and natural elements in the production of NCP. In addition, this approach has shown to be relevant for uncovering synergies, trade-offs, and feedbacks among multiple NCP and quality of life dimensions, as well as interactions among beneficiaries, conflicts, and collaboration around access to capital. Although here we have only described the mechanisms of NCP coproduction, subsequent analyses could unpack the functioning and interactions among different types of capital.

Finally, our analysis provides information on the complexity of coproduction mechanisms that underpin ecosystems management, mobilization, and appropriation, and that drive the functioning and dynamics of social-ecological systems. An in-depth understanding of these mechanisms will help policy makers, managers, and beneficiaries identify changes in NCP coproduction required to meet future challenges of sustainability and adaptation to global changes.

Responses to this article can be read online at: https://www.ecologyandsociety.org/issues/responses. php/12031

\section{Acknowledgments:}

This paper is a contribution from the Transformative Adaptation Research Alliance (TARA, https://research.csiro.aultaral), an international network of researchers and practitioners dedicated to the development and implementation of novel approaches to transformative adaptation to global change. We thank inhabitants of Villar d'Arène and La Grave and regional experts for participation in workshops and interviews, and Marine Gabillet for initiating the participatory process. We are indebted to ServAlp members Nicolas Elleaume, Julia Grosinger, and Agnès Bergeret for challenging discussions for conceptualizing NCP coproduction. We thank Jardin du Lautaret for hosting the research team (UMS 3370 University Grenoble Alpes-CNRS). This work was carried out within the eLSTER site Zone Atelier Alpes. This research was funded through the French Agence Nationale pour la Recherche projects MtnPaths (ANR-16-CE93-0008-01), Investissements d; Avenir CDP Trajectories (ANR-15-IDEX-02), and TRASSE (ANR-17-CE32-0012-01), and the CGIAR Research Program on
Forests, Trees and Agroforestry (CRP-FTA) with financial support from the CGIAR Fund.

\section{Data Availability:}

The qualitative data from workshops and interviews contain personal information that cannot be anonymized and thus cannot be shared.

\section{LITERATURE CITED}

Bally, F., M. Gabillet, D. Laforgue, S. Lavorel, and V. PeyracheGadeau. 2020. La «Crise du Chambon», de nouveaux liens entre territoire, institutions, populations et sciences. Natures, Sciences et Sociétés 28(1):24-34. https://doi.org/10.1051/nss/2020019

Ban, N. C., M. Mills, J. Tam, C. C. Hicks, S. Klain, N. Stoeckl, M. C. Bottrill, J. Levine, R. L. Pressey, T. Satterfield, and K. M. A. Chan. 2013. A social-ecological approach to conservation planning: embedding social considerations. Frontiers in Ecology and the Environment 11(4):194-202. https://doi.org/10.1890/110205

Barnaud, C., E. Corbera, R. Muradian, N. Salliou, C. Sirami, A. Vialatte, J.-P. Choisis, N. Dendoncker, R. Mathevet, C. Moreau, V. Reyes-García, M. Boada, M. Deconchat, C. Cibien, S. Garnier, R. Maneja, and M. Antona. 2018. Ecosystem services, social interdependencies, and collective action: a conceptual framework. Ecology and Society 23(1):15. https://doi. org/10.5751/ES-09848-230115

Bennett, E. M., W. Cramer, A. Begossi, G. Cundill, S. Díaz, B. N. Egoh, I. R. Geijzendorffer, C. B. Krug, S. Lavorel, E. Lazos, L. Lebel, B. Martín-López, P. Meyfroidt, H. A. Mooney, J. L. Nel, U. Pascual, K. Payet, N. P. Harguindeguy, G. D. Peterson, A.-H. Prieur-Richard, B. Reyers, P. Roebeling, R. Seppelt, M. Solan, P. Tschakert, T. Tscharntke, B. L. Turner II, P. H. Verburg, E. F. Viglizzo, P. C. L. White, and G. Woodward. 2015. Linking biodiversity, ecosystem services, and human well-being: three challenges for designing research for sustainability. Current Opinion in Environmental Sustainability 14:76-85. https://doi. org/10.1016/j.cosust.2015.03.007

Bennett, E. M., G. D. Peterson, and L. J. Gordon. 2009. Understanding relationships among multiple ecosystem services. Ecology Letters 12(12):1394-1404. https://doi.org/10.1111/ j.1461-0248.2009.01387.X

Berbés-Blázquez, M., M. J. Bunch, P. R. Mulvihill, G. D. Peterson, and B. van Wendel de Joode. 2017. Understanding how access shapes the transformation of ecosystem services to human wellbeing with an example from Costa Rica. Ecosystem Services 28 (C):320-327. https://doi.org/10.1016/j.ecoser.2017.09.010

Berkes, F., J. Colding, and C. Folke, editors. 2002. Navigating social-ecological systems: building resilience for complexity and change. Cambridge University Press, Cambridge, UK. https://doi. org/10.1017/CBO9780511541957

Bieling, C., T. Plieninger, H. Pirker, and C. R. Vogl. 2014. Linkages between landscapes and human well-being: an empirical exploration with short interviews. Ecological Economics 105:19-30. https://doi.org/10.1016/j.ecolecon.2014.05.013 
Binder, C. R., J. Hinkel, P. W. G. Bots, and C. Pahl-Wostl. 2013. Comparison of frameworks for analyzing social-ecological systems. Ecology and Society 18(4):26. https://doi.org/10.5751/ ES-05551-180426

Collins, S. L., S. R. Carpenter, S. M. Swinton, D. E. Orenstein, D. L. Childers, T. L. Gragson, N. B. Grimm, J. M. Grove, S. L. Harlan, J. P. Kaye, A. K. Knapp, G. P. Kofinas, J. J. Magnuson, W. H. McDowell, J. M. Melack, L. A. Ogden, G. P. Robertson, M. D. Smith, and A. C. Whitmer. 2011. An integrated conceptual framework for long-term social-ecological research. Frontiers in Ecology and the Environment 9(6):351-357. https://doi. org/10.1890/100068

Crouzat, E., M. Mouchet, F. Turkelboom, C. Byczek, J. Meersmans, F. Berger, P. J. Verkerk, and S. Lavorel. 2015. Assessing bundles of ecosystem services from regional to landscape scale: insights from the French Alps. Journal of Applied Ecology 52(5):1145-1155. https://doi.org/10.1111/1365-2664.12502

Daniel, T. C., A. Muhar, A. Arnberger, O. Aznar, J. W. Boyd, K. M. A. Chan, R. Costanza, T. Elmqvist, C. G. Flint, P. H. Gobster, A. Grêt-Regamey, R. Lave, S. Muhar, M. Penker, R. G. Ribe, T. Schauppenlehner, T. Sikor, I. Soloviy, M. Spierenburg, K. Taczanowska, J. Tam, and A. von der Dunk. 2012. Contributions of cultural services to the ecosystem services agenda. Proceedings of the National Academy of Sciences 109(23):8812-8819. https:// doi.org/10.1073/pnas.1114773109

Dendoncker, N., F. Boeraeve, E. Crouzat, M. Dufrêne, A. König, and C. Barnaud. 2018. How can integrated valuation of ecosystem services help understanding and steering agroecological transitions? Ecology and Society 23(1):12. https://doi. org/10.5751/ES-09843-230112

Díaz, S., S. Demissew, J. Carabias, C. Joly, M. Lonsdale, N. Ash, A. Larigauderie, J. R. Adhikari, S. Arico, A. Báldi, A. Bartuska, I. A. Baste, A. Bilgin, E. Brondizio, K. M. A. Chan, V. E. Figueroa, A. Duraiappah, M. Fischer, R. Hill, T. Koetz, P. Leadley, P. Lyver, G. M. Mace, B. Martin-Lopez, M. Okumura, D. Pacheco, U. Pascual, E. S. Pérez, B. Reyers, E. Roth, O. Saito, R. J. Scholes, N. Sharma, H. Tallis, R. Thaman, R. Watson, T. Yahara, Z. A. Hamid, C. Akosim, Y. Al-Hafedh, R. Allahverdiyev, E. Amankwah, T. S. Asah, Z. Asfaw, G. Bartus, A. L. Brooks, J. Caillaux, G. Dalle, D. Darnaedi, A. Driver, G. Erpul, P. EscobarEyzaguirre, P. Failler, A. M. M. Fouda, B. Fu, H. Gundimeda, S. Hashimoto, F. Homer, S. Lavorel, G. Lichtenstein, W. A. Mala, W. Mandivenyi, P. Matczak, C. Mbizvo, M. Mehrdadi, J. P. Metzger, J. B. Mikissa, H. Moller, H. A. Mooney, P. Mumby, H. Nagendra, C. Nesshover, A. A. Oteng-Yeboah, G. Pataki, M. Roué, J. Rubis, M. Schultz, P. Smith, R. Sumaila, K. Takeuchi, S. Thomas, M. Verma, Y. Yeo-Chang, and D. Zlatanova. 2015. The IPBES conceptual framework - connecting nature and people. Current Opinion in Environmental Sustainability 14:1-16. https:// doi.org/10.1016/j.cosust.2014.11.002

Díaz, S., U. Pascual, M. Stenseke, B. Martín-López, R. T. Watson, Z. Molnár, R. Hill, K. M. A. Chan, I. A. Baste, K. A. Brauman, S. Polasky, A. Church, M. Lonsdale, A. Larigauderie, P. W. Leadley, A. P. E. van Oudenhoven, F. van der Plaat, M. Schröter, S. Lavorel, Y. Aumeeruddy-Thomas, E. Bukvareva, K. Davies, S. Demissew, G. Erpul, P. Failler, C. A. Guerra, C. L. Hewitt, H.
Keune, S. Lindley, and Y. Shirayama. 2018. Assessing nature's contributions to people. Science 359(6373):270-272. https://doi. org/10.1126/science.aap8826

Ellis, E. C., U. Pascual, and O. Mertz. 2019. Ecosystem services and nature's contribution to people: negotiating diverse values and trade-offs in land systems. Current Opinion in Environmental Sustainability 38:86-94. https://doi.org/10.1016/j.cosust.2019.05.001

Fedele, G., B. Locatelli, and H. Djoudi. 2017. Mechanisms mediating the contribution of ecosystem services to human wellbeing and resilience. Ecosystem Services 28(A):43-54. https://doi. org/10.1016/j.ecoser.2017.09.011

Felipe-Lucia, M. R., B. Martín-López, S. Lavorel, L. BerraqueroDíaz, J. Escalera-Reyes, and F. A. Comín. 2015. Ecosystem services flows: why stakeholders' power relationships matter. Plos One 10(7):e0132232. https://doi.org/10.1371/journal.pone.0132232

Fischer, A., and A. Eastwood. 2016. Coproduction of ecosystem services as human-nature interactions - an analytical framework. Land Use Policy 52:41-50. https://doi.org/10.1016/j.landusepol.2015.12.004

Gandrud, C., J. Allaire, K. Russell, B. Lewis, K. Kuo, C. Sese, P. Ellis, J. Owen, and J. Rogers. 2016. networkD3: D3 JavaScript network graphs from $R$. R package version 0.2. [online] URL: https://cran.r-project.org/package=networkD3

García-Nieto, A. P., E. Huland, C. Quintas-Soriano, I. IniestaArandia, M. García-Llorente, I. Palomo, and B. Martín-López. 2019. Evaluating social learning in participatory mapping of ecosystem services. Ecosystems and People 15(1):257-268. https:// doi.org/10.1080/26395916.2019.1667875

Grêt-Regamey, A., S. H. Brunner, J. Altwegg, and P. Bebi. 2013. Facing uncertainty in ecosystem services-based resource management. Journal of Environmental Management 127 (Supplement):S145-S154.

Haida, C., J. Rüdisser, and U. Tappeiner. 2016. Ecosystem services in mountain regions: experts' perceptions and research intensity. Regional Environmental Change 16(7):1989-2004. https://doi. org/10.1007/s10113-015-0759-4

Haines-Young, R., and M. Potschin. 2010. The links between biodiversity, ecosystem services and human well-being. Pages 110-139 in D. G. Raffaelli and C. L. J. Frid, editors. Ecosystem ecology: anew synthesis. Cambridge University Press, Cambridge, UK. https://doi.org/10.1017/CBO9780511750458.007

Hernández-Morcillo, M., T. Plieninger, and C. Bieling. 2013. An empirical review of cultural ecosystem service indicators. Ecological Indicators 29:434-444. https://doi.org/10.1016/j. ecolind.2013.01.013

Iniesta-Arandia, I., M. García-Llorente, P. A. Aguilera, C. Montes, and B. Martín-López. 2014. Socio-cultural valuation of ecosystem services: uncovering the links betwenn values, drivers of change, and human well-being. Ecological Economics 108:36-48. https://doi.org/10.1016/j.ecolecon.2014.09.028

Intergovernmental Science-Policy Platform on Biodiversity and Ecosystem Services (IPBES). 2019. Global assessment report on biodiversity and ecosystem services. E. S. Brondizio, J. Settele, S. 
Díaz, and H. T. Ngo, editors. IPBES Secretariat, Bonn, Germany. [online] URL: https://ipbes.net/global-assessment

Jones, L., L. Norton, Z. Austin, A. L. Browne, D. Donovan, B. A. Emmett, Z. J. Grabowski, D. C. Howard, J. P. G. Jones, J. O. Kenter, W. Manley, C. Morris, D. A. Robinson, C. Short, G. M. Siriwardena, C. J. Stevens, J. Storkey, R. D. Waters, and G. F. Willis. 2016. Stocks and flows of natural and human-derived capital in ecosystem services. Land Use Policy 52:151-162. https:// doi.org/10.1016/j.landusepol.2015.12.014

Kadykalo, A. N., M. D. López-Rodriguez, J. Ainscough, N. Droste, H. Ryu, G. Ávila-Flores, S. Le Clec'h, M. C. Muñoz, L. Nilsson, S. Rana, P. Sarkar, K. J. Sevecke, and Z. V. Harmáčková. 2019. Disentangling 'ecosystem services' and 'nature's contributions to people'. Ecosystems and People 15(1):269-287. https://doi.org/10.1080/26395916.2019.1669713

Lamarque, P., U. Tappeiner, C. Turner, M. Steinbacher, R. D. Bardgett, U. Szukics, M. Schermer, and S. Lavorel. 2011. Stakeholder perceptions of grassland ecosystem services in relation to knowledge on soil fertility and biodiversity. Regional Environmental Change 11:791-804. https://doi.org/10.1007/ $\underline{\text { s10113-011-0214-0 }}$

Lavorel, S., M. J. Colloff, B. Locatelli, R. Gorddard, S. M. Prober, M. Gabillet, C. Devaux, D. Laforgue, and V. Peyrache-Gadeau. 2019. Mustering the power of ecosystems for adaptation to climate change. Environmental Science and Policy 92:87-97. https://doi.org/10.1016/j.envsci.2018.11.010

Lavorel, S., K. Grigulis, G. Leitinger, M. Kohler, U. Schirpke, and U. Tappeiner. 2017. Historical trajectories in land use pattern and grassland ecosystem services in two European alpine landscapes. Regional Environmental Change 17(8):2251-2264. https://doi. org/10.1007/s10113-017-1207-4

Lavorel, S., B. Locatelli, M. J. Colloff, and E. Bruley. 2020. Coproducing ecosystem services for adapting to climate change. Philosophical Transactions of the Royal Society $B 375$ (1794):20190119. https://doi.org/10.1098/rstb.2019.0119

Lele, S., O. Springate-Baginski, R. Lakerveld, D. Deb, and P. Dash. 2013. Ecosystem services: origins, contributions, pitfalls, and alternatives. Conservation and Society 11(4):343-358. https:// doi.org/10.4103/0972-4923.125752

Liu, J., T. Dietz, S. R. Carpenter, C. Folke, M. Alberti, C. L. Redman, S. H. Schneider, E. Ostrom, A. N. Pell, J. Lubchenco, W. W. Taylor, Z. Ouyang, P. Deadman, T. Kratz, and W. Provencher. 2007. Coupled human and natural systems. Ambio 36(8):639-649. https://doi.org/10.1579/0044-7447(2007)36[639: CHANS]2.0.CO;2

Locatelli, B., A. Vallet, G. Fedele, and B. Rapidel. 2017. Analyzing ecosystem services to manage territories to manage territories. in P. Caron, É. Valette, T. Wassenaar, G. Coppens d'Eeckenbrugge, and V. Papazian, editors. Living territories to transform the world. Éditions Quae, Versailles, France. [online] URL: https://www. cifor.org/knowledge/publication/6396/

Martín-López, B., I. Leister, P. L. Cruz, I. Palomo, A. GrêtRegamey, P. A. Harrison, S. Lavorel, B. Locatelli, S. Luque, and A. Walz. 2019. Nature's contributions to people in mountains: a review. Plos One 14(6):e0217847. https://doi.org/10.1371/journal. pone. 0217847
Maslow, A. H. 1943. A theory of human motivation. Psychological Review 50(4):370-396. https://doi.org/10.1037/ $\underline{\mathrm{h} 0054346}$

Mastrángelo, M. E., N. Pérez-Harguindeguy, L. Enrico, E. Bennett, S. Lavorel, G. S. Cumming, D. Abeygunawardane, L. D. Amarilla, B. Burkhard, B. N. Egoh, L. Frishkoff, L. Galetto, S. Huber, D. S. Karp, A. Ke, E. Kowaljow, A. Kronenburg-García, B. Locatelli, B. Martín-López, P. Meyfroidt, T. H. Mwampamba, J. Nel, K. A. Nicholas, C. Nicholson, E. Oteros-Rozas, S. J. Rahlao, C. Raudsepp-Hearne, T. Ricketts, U. B. Shrestha, C. Torres, K. J. Winkler, and K. Zoeller. 2019. Key knowledge gaps to achieve global sustainability goals. Nature Sustainability 2:1115-1121. https://doi.org/10.1038/s41893-019-0412-1

Mengist, W., T. Soromessa, and G. Legese. 2020. Ecosystem services research in mountainous regions: a systematic literature review on current knowledge and research gaps. Science of the Total Environment 702:134581. https://doi.org/10.1016/j. scitotenv.2019.134581

Millennium Ecosystem Assessment. 2005. Ecosystems and human well-being: synthesis. Island Press, Washington, D.C., USA. [online] URL: https://www.millenniumassessment.org/documents/ document.356.aspx.pdf

Ostrom, E. 2009. A general framework for analyzing sustainability of social-ecological systems. Science 325 (5939):419-422. https://doi.org/10.1126/science.1172133

Outeiro, L., E. Ojea, J. G. Rodrigues, A. Himes-Cornell, A. Belgrano, Y. Liu, E. Cabecinha, C. Pita, G. Macho, and S. Villasante. 2017. The role of non-natural capital in the coproduction of marine ecosystem services. International Journal of Biodiversity Science, Ecosystem Services and Management 13 (3):35-50. https://doi.org/10.1080/21513732.2017.1415973

Palomo, I., M. R. Felipe-Lucia, E. M. Bennett, B. Martín-López, and U. Pascual. 2016. Disentangling the pathways and effects of ecosystem service coproduction. Pages 245-283 in G. Woodward and D. A. Bohan, editors. Ecosystem services: from biodiversity to society, part 2. Advances in Ecological Research 54. Academic Press, London, UK. https://doi.org/10.1016/bs.aecr.2015.09.003

Palomo, I., B. Martín-López, C. López-Santiago, and C. Montes. 2011. Participatory scenario planning for protected areas management under the ecosystem services framework: the Doñana social-ecological system in southwestern Spain. Ecology and Society 16(1):23. https://doi.org/10.5751/ES-03862-160123

Pascual, U., P. Balvanera, S. Díaz, G. Pataki, E. Roth, M. Stenseke, R. T. Watson, E. Başak Dessane, M. Islar, E. Kelemen, V. Maris, M. Quaas, S. M. Subramanian, H. Wittmer, A. Adlan, S. Ahn, Y. S. Al-Hafedh, E. Amankwah, S. T. Asah, P. Berry, A. Bilgin, S. J. Breslow, C. Bullock, D. Cáceres, H. Daly-Hassen, E. Figueroa, C. D. Golden, E. Gómez-Baggethun, D. GonzálezJiménez, J. Houdet, H. Keune, R. Kumar, K. Ma, P. H. May, A. Mead, P. O'Farrell, R. Pandit, W. Pengue, R. Pichis-Madruga, F. Popa, S. Preston, D. Pacheco-Balanza, H. Saarikoski, B. B. Strassburg, M. van den Belt, M. Verma, F. Wickson, and N. Yagi. 2017. Valuing nature's contributions to people: the IPBES approach. Current Opinion in Environmental Sustainability 26-27:7-16. https://doi.org/10.1016/j.cosust.2016.12.006 
Plieninger, T., M. Torralba, T. Hartel, and N. Fagerholm. 2019. Perceived ecosystem services synergies, trade-offs, and bundles in European high nature value farming landscapes. Landscape Ecology 34(7):1565-1581. https://doi.org/10.1007/s10980-019-00775-1

Quétier, F., F. Rivoal, P. Marty, J. de Chazal, W. Thuiller, and S. Lavorel. 2010. Social representations of an alpine grassland landscape and socio-political discourses on rural development. Regional Environmental Change 10(2):119-130. https://doi. org/10.1007/s10113-009-0099-3

Quétier, F., A. Thébault, and S. Lavorel. 2007. Plant traits in a state and transition framework as markers of ecosystem response to land-use change. Ecological Monographs 77(1):33-52. https:// doi.org/10.1890/06-0054

Raymond, C. M., M. Giusti, and S. Barthel. 2018. An embodied perspective on the coproduction of cultural ecosystem services: toward embodied ecosystems. Journal of Environmental Planning and Management 61(5-6):778-799. https://doi.org/10.1080/0964$\underline{0568.2017 .1312300}$

Reyers, B., R. Biggs, G. S. Cumming, T. Elmqvist, A. P. Hejnowicz, and S. Polasky. 2013. Getting the measure of ecosystem services: a social-ecological approach. Frontiers in Ecology and the Environment 11(5):268-273. https://doi.org/10.1890/120144

Ryan, R. M., and E. L. Deci. 2001. On happiness and human potentials: a review of research on hedonic and eudaimonic wellbeing. Annual Review of Psychology 52:141-166. https://doi. org/10.1146/annurev.psych.52.1.141

Saidi, N., and C. Spray. 2018. Ecosystem services bundles: challenges and opportunities for implementation and further research. Environmental Research Letters 13(11):113001. https:// doi.org/10.1088/1748-9326/aae5e0

Sarkki, S. 2017. Governance services: co-producing human wellbeing with ecosystem services. Ecosystem Services 27(A):82-91. https://doi.org/10.1016/i.ecoser.2017.08.003

Schermer, M., I. Darnhofer, K. Daugstad, M. Gabillet, S. Lavorel, and M. Steinbacher. 2016. Institutional impacts on the resilience of mountain grasslands: an analysis based on three European case studies. Land Use Policy 52:382-391. https://doi.org/10.1016/ j.landusepol.2015.12.009

Schneider, F., and S. Rist. 2014. Envisioning sustainable water futures in a transdisciplinary learning process: combining normative, explorative, and participatory scenario approaches. Sustainability Science 9(4):463-481. https://doi.org/10.1007/ s11625-013-0232-6

Spangenberg, J. H., C. Görg, D. T. Truong, V. Tekken, J. V. Bustamante, and J. Settele. 2014. Provision of ecosystem services is determined by human agency, not ecosystem functions. Four case studies. International Journal of Biodiversity Science, Ecosystem Services and Management 10(1):40-53. https://doi. org/10.1080/21513732.2014.884166

Steffen, W., K. Richardson, J. Rockström, S. E. Cornell, I. Fetzer, E. M. Bennett, R. Biggs, S. R. Carpenter, W. de Vries, C. A. de Wit, C. Folke, D. Gerten, J. Heinke, G. M. Mace, L. M. Persson, V. Ramanathan, B. Reyers, and S. Sörlin. 2015. Planetary boundaries: guiding human development on a changing planet. Science 347(6223):1259855. https://doi.org/10.1126/science.1259855

Temperli, C., H. Bugmann, and C. Elkin. 2012. Adaptive management for competing forest goods and services under climate change. Ecological Applications 22(8):2065-2077. https:// doi.org/10.1890/12-0210.1

Torralba, M., E. Oteros-Rozas, G. Moreno, and T. Plieninger. 2018. Exploring the role of management in the coproduction of ecosystem services from Spanish wooded rangelands. Rangeland Ecology and Management 71(5):549-559. https://doi.org/10.1016/ j.rama.2017.09.001

Vallet, A., B. Locatelli, H. Levrel, N. Dendoncker, C. Barnaud, and Y. Quispe Conde. 2019. Linking equity, power, and stakeholders' roles in relation to ecosystem services. Ecology and Society 24(2):14. https://doi.org/10.5751/ES-10904-240214

Vialatte, A., C. Barnaud, J. Blanco, A. Ouin, J.-P. Choisis, E. Andrieu, D. Sheeren, S. Ladet, M. Deconchat, F. Clément, D. Esquerré, and C. Sirami. 2019. A conceptual framework for the governance of multiple ecosystem services in agricultural landscapes Landscape Ecology 34:1653-1673. https://doi. org/10.1007/s10980-019-00829-4

Zoderer, B. M., E. Tasser, S. Carver, and U. Tappeiner. 2019. Stakeholder perspectives on ecosystem service supply and ecosystem service demand bundles. Ecosystem Services 37:100938. https://doi.org/10.1016/j.ecoser.2019.100938 


\section{APPENDIX 1}

2 Table A1.1: Surface area (in ha and \%) of the different landscape units on the Pays de la Meije (land 3 cover GIS analysis)

\begin{tabular}{lcc} 
Landscape units & $\begin{array}{l}\text { Surface } \\
\text { (ha) }\end{array}$ & $\begin{array}{l}\text { Land cover } \\
(\%)\end{array}$ \\
\hline Rocks & 9192 & $46 \%$ \\
Summer Pastures & 5355 & $27 \%$ \\
Grazed Terraces & 1721 & $9 \%$ \\
Ice and snow & 1602 & $8 \%$ \\
Larch Meadows & 670 & $<3 \%$ \\
Shrublands & 651 & $<3 \%$ \\
Hay Meadows & 536 & $<3 \%$ \\
Forests & 321 & $<2 \%$ \\
Waterbodies & 15 & $<1 \%$ \\
Croplands & 4 & $<1 \%$ \\
Built up & 2 & $<1 \%$
\end{tabular}

4 
Table A1.2: Stakeholders description and participation

\begin{tabular}{|c|c|c|c|c|c|c|c|c|}
\hline $\begin{array}{l}\mathbf{N} \\
0\end{array}$ & Categories & Gender & Age & $\begin{array}{c}\text { Scale of } \\
\text { action }\end{array}$ & $\begin{array}{c}\text { Local } \\
\text { workshop }\end{array}$ & $\begin{array}{c}\text { Regional } \\
\text { Workshop }\end{array}$ & Interviews & $\begin{array}{l}\text { Validation } \\
\text { workshop }\end{array}$ \\
\hline 1 & $\begin{array}{l}\text { Regional experts } \\
\text { (Agriculture) }\end{array}$ & M & $30-40$ & Regional & & $\mathrm{X}$ & & \\
\hline 2 & $\begin{array}{l}\text { Representatives of local and } \\
\text { regional institutions }\end{array}$ & M & $40-50$ & Departmental & & & $X$ & \\
\hline 3 & $\begin{array}{l}\text { Representatives of nature } \\
\text { conservation organizations }\end{array}$ & M & $60-70$ & Regional & & & $\mathrm{X}$ & \\
\hline 4 & $\begin{array}{l}\text { Representatives of nature } \\
\text { conservation organizations }\end{array}$ & M & $40-50$ & Departmental & & $\mathrm{X}$ & & \\
\hline 5 & Tourism professionals & $\mathrm{M}$ & $60-70$ & Local & $\mathrm{X}$ & & & \\
\hline 6 & Regional experts (Tourism) & $\mathrm{M}$ & $50-60$ & Regional & & $\mathrm{X}$ & & \\
\hline 7 & $\begin{array}{l}\text { Representatives of regional } \\
\text { institutions }\end{array}$ & $\mathrm{F}$ & $50-60$ & Departmental & & $\mathrm{X}$ & & \\
\hline 8 & $\begin{array}{l}\text { Representatives of nature } \\
\text { conservation organizations }\end{array}$ & M & $40-50$ & local & & & & $\mathrm{X}$ \\
\hline 9 & Second home's owner & $\mathrm{M}$ & $40-50$ & Local & $\mathrm{X}$ & & & $\mathrm{X}$ \\
\hline 10 & $\begin{array}{l}\text { Farmers and other } \\
\text { agricultural stakeholders }\end{array}$ & $\mathrm{F}$ & $40-50$ & Regional & & & $\mathrm{X}$ & \\
\hline 11 & Regional experts (Risks) & M & $30-40$ & Regional & & $\mathrm{X}$ & & \\
\hline 12 & Staff of residential services & $\mathrm{F}$ & $60-70$ & Local & $\mathrm{X}$ & & & $\mathrm{X}$ \\
\hline 13 & Local elected representatives & $\mathrm{M}$ & $60-70$ & & & & $\mathrm{X}$ & \\
\hline 14 & Tourism professionals & $\mathrm{F}$ & $60-70$ & Local & $\mathrm{X}$ & & & \\
\hline 15 & Staff of residential services & $\mathrm{F}$ & $30-40$ & Local & $\mathrm{X}$ & & & \\
\hline 16 & $\begin{array}{l}\text { Local elected representatives } \\
\& \text { Tourism professionals }\end{array}$ & M & $60-70$ & Local & & $\mathrm{X}$ & & \\
\hline 17 & Tourism professionals & $\mathrm{F}$ & $40-50$ & Local & & & & $\mathrm{X}$ \\
\hline 18 & Tourism professionals & $\mathrm{M} \& \mathrm{~F}$ & $40-50$ & Local & & & $\mathrm{X}$ & \\
\hline 19 & Tourism professionals & $\mathrm{M}$ & $40-50$ & Local & $\mathrm{X}$ & & & \\
\hline 20 & Tourism professionals & $\mathrm{F}$ & $40-50$ & Local & & & $\mathrm{X}$ & \\
\hline 21 & $\begin{array}{l}\text { Local elected representatives } \\
\& \text { Tourism professionals }\end{array}$ & $\mathrm{M}$ & $40-50$ & Local & & $\mathrm{X}$ & & \\
\hline 22 & $\begin{array}{l}\text { Representatives of regional } \\
\text { institutions }\end{array}$ & $\mathrm{M}$ & $50-60$ & Regional & & $\mathrm{X}$ & & \\
\hline 23 & Tourism professionals & $\mathrm{M}$ & $30-40$ & Local & & & $\mathrm{X}$ & \\
\hline 24 & Student/Inhabitant & $\mathrm{M}$ & $10-20$ & Local & & & $\mathrm{X}$ & \\
\hline 25 & Tourism professionals & $\mathrm{M}$ & $40-50$ & Departmental & & $\mathrm{X}$ & & \\
\hline 26 & Regional experts (Climate) & $\mathrm{M}$ & $30-40$ & Regional & & $\mathrm{X}$ & & \\
\hline 27 & Tourism professionals & $\mathrm{F}$ & $40-50$ & Local & $\mathrm{X}$ & & & $\mathrm{X}$ \\
\hline 28 & $\begin{array}{l}\text { Representatives of local and } \\
\text { regional institutions }\end{array}$ & $\mathrm{F}$ & $30-40$ & Local & & & $\mathrm{X}$ & \\
\hline 29 & $\begin{array}{l}\text { Representatives of nature } \\
\text { conservation organizations }\end{array}$ & $\mathrm{F}$ & $50-60$ & Departmental & & & $\mathrm{X}$ & \\
\hline 30 & Tourism professionals & $\mathrm{M}$ & $40-50$ & Local & $\mathrm{X}$ & & & $\mathrm{X}$ \\
\hline 31 & Student/Inhabitant & $\mathrm{F}$ & $10-20$ & Local & & & $\mathrm{X}$ & \\
\hline 32 & Student/Inhabitant & $\mathrm{M}$ & $10-20$ & Local & & & $\mathrm{X}$ & \\
\hline 33 & Tourism professionals & $\mathrm{M}$ & $20-30$ & Local & & & & $\mathrm{X}$ \\
\hline 34 & $\begin{array}{l}\text { Farmers and other } \\
\text { agricultural stakeholders }\end{array}$ & M & $40-50$ & Regional & & $\mathrm{X}$ & & \\
\hline 35 & Tourism professionals & $\mathrm{F}$ & $30-40$ & Local & $\mathrm{X}$ & & & \\
\hline \multicolumn{2}{|c|}{ Total number of participants } & & & & 9 & 11 & 12 & 7 \\
\hline
\end{tabular}


Table A1.3 : Description of all nature contribution to people perceived by stakeholders

\begin{tabular}{|c|c|c|c|}
\hline $\begin{array}{c}\text { NCP category } \\
\text { perceived by } \\
\text { stakeholders }\end{array}$ & $\begin{array}{c}\text { Landscape } \\
\text { attractiveness }\end{array}$ & Habitability & Rurality maintenance \\
\hline $\begin{array}{l}\text { 3. Regulation of air } \\
\text { quality }\end{array}$ & Pure air/ depollution & Pure air/ depollution & not cited \\
\hline $\begin{array}{l}\text { 6. Regulation of } \\
\text { freshwater quantity }\end{array}$ & $\begin{array}{l}\text { Recreational activities on } \\
\text { lake, rivers and } \\
\text { psychological link to } \\
\text { water }\end{array}$ & $\begin{array}{l}\text { Hydropower } \\
\text { psychological link to } \\
\text { water and recreational } \\
\text { activities (lake and river) }\end{array}$ & Drinking (animals) \\
\hline $\begin{array}{l}\text { 7. Regulation of } \\
\text { freshwater quality }\end{array}$ & $\begin{array}{l}\text { Leisure/recreational } \\
\text { activities }\end{array}$ & Drinking & not cited \\
\hline $\begin{array}{l}\text { 8. Formation/ } \\
\text { protection of soil }\end{array}$ & not cited & not cited & caused by/manage \\
\hline $\begin{array}{l}\text { 9. Regulation of hazard } \\
\text { and extreme events }\end{array}$ & $\begin{array}{l}\text { Floods, rock fall, } \\
\text { avalanches, landslides }\end{array}$ & $\begin{array}{l}\text { Floods, rock fall, } \\
\text { avalanches, landslides }\end{array}$ & \\
\hline 12. Food and feed & $\begin{array}{l}\text { Dairy products, honey, } \\
\text { local production }\end{array}$ & $\begin{array}{l}\text { Dairy products, honey, } \\
\text { local production }\end{array}$ & $\begin{array}{l}\text { Production of food from } \\
\text { domestic animals } \\
\text { Production of feed for } \\
\text { animals } \\
\text { Production of plants, dairy } \\
\text { products, honey... } \\
\text { gardening production } \\
\end{array}$ \\
\hline 14. Medicinal resources & not cited & Wild plants and trees & not cited \\
\hline $\begin{array}{l}\text { 15. Learning and } \\
\text { inspiration }\end{array}$ & $\begin{array}{l}\text { Education, information, } \\
\text { inspiration, self- } \\
\text { development }\end{array}$ & $\begin{array}{l}\text { Education, information, } \\
\text { inspiration, self- } \\
\text { development }\end{array}$ & \\
\hline $\begin{array}{l}\text { 16. Physical and } \\
\text { psychological } \\
\text { experiences }\end{array}$ & $\begin{array}{l}\text { Healing, relaxation, } \\
\text { recreation, leisure, } \\
\text { tourism, aesthetic } \\
\text { enjoyment }\end{array}$ & $\begin{array}{l}\text { Healing, relaxation, } \\
\text { recreation, leisure, } \\
\text { aesthetic enjoyment }\end{array}$ & not cited \\
\hline $\begin{array}{l}\text { 17. Supporting } \\
\text { identities }\end{array}$ & $\begin{array}{l}\text { Religious, spiritual } \\
\text { Sense of place (linked to } \\
\text { heritage, mountain } \\
\text { culture) } \\
\text { Local products (dish) }\end{array}$ & $\begin{array}{l}\text { Religious, spiritual and } \\
\text { social cohesion } \\
\text { Sense of place, belonging } \\
\text { (linked to heritage, } \\
\text { mountain culture) } \\
\text { Local products (dish) } \\
\end{array}$ & $\begin{array}{l}\text { Social cohesion } \\
\text { Sense of place, belonging } \\
\text { (linked to heritage, } \\
\text { mountain culture) } \\
\text { Local products (dish) }\end{array}$ \\
\hline
\end{tabular}




\begin{tabular}{|c|c|c|c|c|c|}
\hline NCP & QOL & Nature & $\begin{array}{c}\text { Arrow 3: } \\
\text { Direct drivers } \rightarrow \text { Nature } \\
\\
\text { Co-production type 1 } \\
\text { (ecosystem and landscape } \\
\text { management) } \\
\end{array}$ & $\begin{array}{c}\text { Arrow 4: } \\
\text { Nature } \rightarrow \text { NCP } \\
\text { Co-production type } 2 \\
\text { (mobilization, harvesting, } \\
\text { physical access) } \\
\end{array}$ & $\begin{array}{c}\text { Arrow 8: } \\
\text { NCP } \rightarrow \text { Quality of life } \\
\text { Co-production type } 3 \\
\text { (appropriation, social access, } \\
\text { appreciation) } \\
\end{array}$ \\
\hline \multirow[t]{3}{*}{$\begin{array}{l}\text { Fodder } \\
\text { production } \\
\text { (Feed) }\end{array}$} & $\mathrm{R}$ & \multirow[t]{3}{*}{$\begin{array}{c}\text { Agricultural } \\
\text { lands }\end{array}$} & $\begin{array}{l}\text { What: Farming practices } \\
\text { Anthropogenic assets } \\
\text { MC: Farm infrastructures, tools } \\
\text { and machines, fertilizer, tracks } \\
\text { FC: Subsidies from CAP } \\
\text { influencing practices (ICNH, } \\
\text { MAE) } \\
\text { HC: Full or part time labour, } \\
\text { knowledge on terraced farming, } \\
\text { motivation to maintain traditional } \\
\text { practices } \\
\text { Institution \& governance } \\
\text { SC: Local network and } \\
\text { organisation, support from } \\
\text { institution (Chamber of } \\
\text { Agriculture, PNE, AFP), land } \\
\text { tenures and allocation } \\
\text { Indirect SC: Policies influencing } \\
\text { practices (CAP) }\end{array}$ & $\begin{array}{l}\text { What: Mowing and grazing } \\
\text { Anthropogenic assets } \\
\text { MC: Tools and machines, animals, } \\
\text { tracks } \\
\text { FC: Subsidies from CAP } \\
\text { influencing practices (ICNH, } \\
\text { MAE), supply chain for livestock/ } \\
\text { transhumance } \\
\text { HC: Full or part time labour, } \\
\text { knowledge on terraced farming } \\
\text { and grazing, motivation to } \\
\text { maintain traditional practices } \\
\text { Institution \& governance } \\
\text { SC: Local organisation, Policies } \\
\text { influencing practices (CAP), Local } \\
\text { support (Chamber of Agriculture, } \\
\text { National Park, AFP) }\end{array}$ & $\begin{array}{l}\text { What: Trading livestock } \\
\text { (selling) } \\
\text { Anthropogenic assets } \\
\text { MC: Selling infrastructures } \\
\text { (vehicles) } \\
\text { FC: Supply chain and market } \\
\text { (network) } \\
\text { HC: Knowledge on market and } \\
\text { sales } \\
\\
\text { Institution \& governance } \\
\text { SC: Local and regional market } \\
\text { organisation and networks }\end{array}$ \\
\hline & $\mathrm{H}$ & & None & None & None \\
\hline & A & & None & None & None \\
\hline \multirow[t]{3}{*}{$\begin{array}{c}\text { Food } \\
\text { production }\end{array}$} & $\mathrm{R}$ & \multirow[t]{3}{*}{$\begin{array}{c}\text { Agricultural } \\
\text { lands }\end{array}$} & $\begin{array}{l}\text { Cropping practices } \\
\text { Anthropogenic assets } \\
\text { MC: Farm infrastructures, tools } \\
\text { and machines, fertilizer, seeds } \\
\text { FC: Subsidies from CAP } \\
\text { influencing practices (ICNH, } \\
\text { MAE) } \\
\text { Institution \& governance } \\
\text { SC: Local support (Chamber of } \\
\text { Agriculture, PNE, AFP), land } \\
\text { properties and allocation } \\
\text { Indirect SC: Policies influencing } \\
\text { practices (CAP) }\end{array}$ & $\begin{array}{l}\text { Grazing, transhumance, } \\
\text { vegetable harvesting } \\
\text { Anthropogenic assets } \\
\text { MC: livestock } \\
\text { FC: Subsidies from CAP } \\
\text { influencing practices (ICNH, } \\
\text { MAE), } \\
\text { HC: Knowledge about grazing, } \\
\text { herding. Workforce } \\
\text { Institution \& governance } \\
\text { SC: Local organisation, Policies } \\
\text { influencing practices (CAP), Local } \\
\text { support (Chamber of Agriculture, } \\
\text { PNE, AFP), supply chain for } \\
\text { livestock and transhumance, Local } \\
\text { market }\end{array}$ & $\begin{array}{l}\text { Trading agricultural products } \\
\text { (transforming and selling) } \\
\text { Anthropogenic assets } \\
\text { MC: Selling and transformation } \\
\text { infrastructures } \\
\text { FC: Supply chain and market } \\
\text { (network) } \\
\text { HC: Knowledge on product } \\
\text { transformation, packaging, } \\
\text { communication and sales } \\
\text { Institution \& governance } \\
\text { SC: Local markets organisation } \\
\text { and networks }\end{array}$ \\
\hline & $\mathrm{H}$ & & None & None & \multirow{2}{*}{$\begin{array}{l}\text { What: Consume products (by } \\
\text { local people and visitors) } \\
\text { Anthropogenic assets: } \\
\text { MC: Infrastructure (market) } \\
\text { FC: Equity in payment options } \\
\text { HC: Knowledge, values and } \\
\text { preferences for local products } \\
\\
\text { Institution and governance: } \\
\text { SC: Supply chain for products, } \\
\text { information, consumption patterns }\end{array}$} \\
\hline & A & & None & None & \\
\hline
\end{tabular}




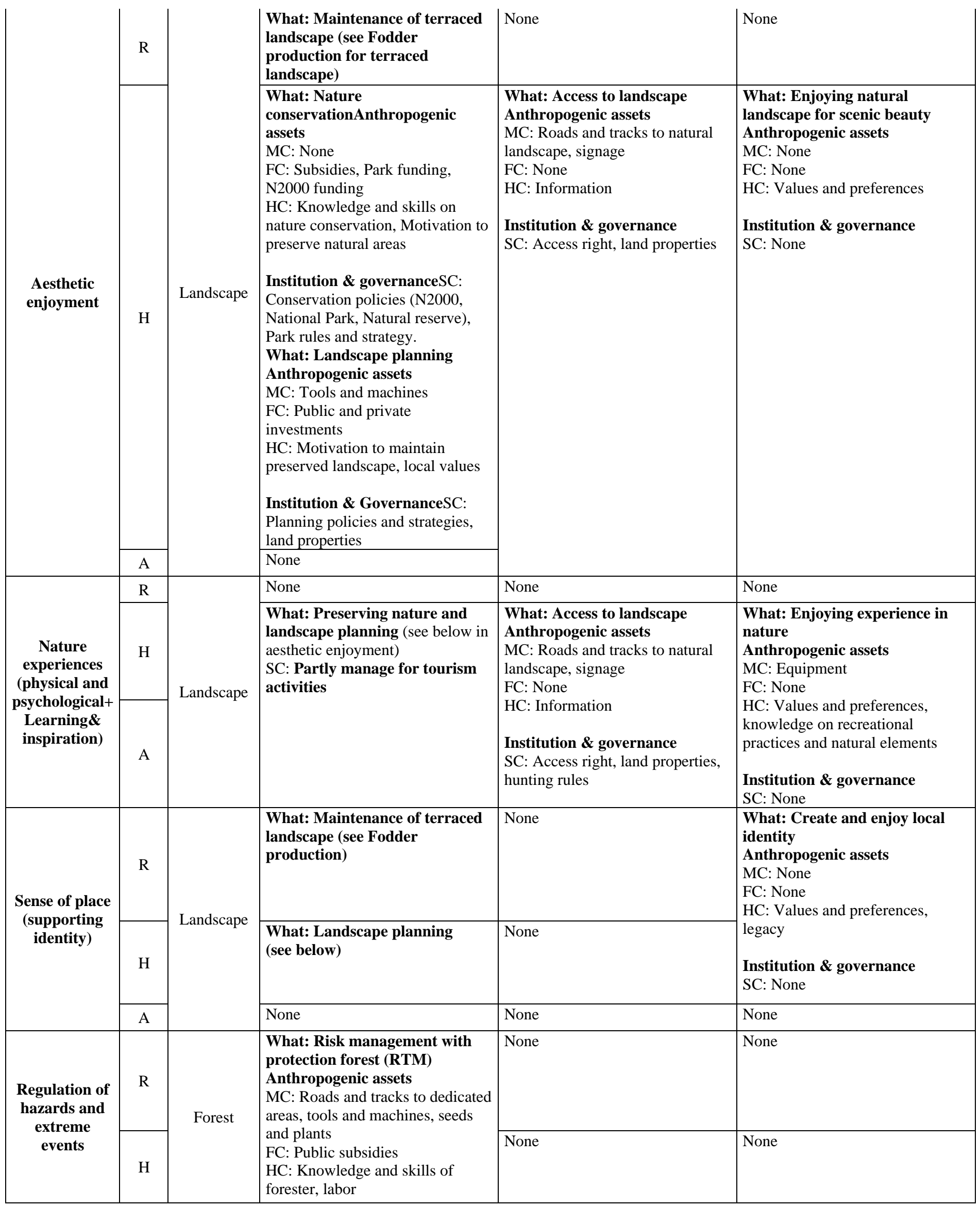




\begin{tabular}{|c|c|c|c|c|c|}
\hline & A & & $\begin{array}{l}\text { Institution \& governance } \\
\text { SC: Forest and risk national } \\
\text { institution, access right, land } \\
\text { properties }\end{array}$ & None & None \\
\hline \multirow[t]{3}{*}{$\begin{array}{l}\text { Regulation of } \\
\text { freshwater }\end{array}$} & $\mathrm{R}$ & & Not intentional & $\begin{array}{l}\text { What: Drinking for animals } \\
\text { Anthropogenic assets } \\
\text { MC: Pipe and tools } \\
\text { FC: Equity of farmer } \\
\text { HC: Knowledge and skills } \\
\text { Institution \& governance } \\
\text { SC: Rules on water withdrawal, } \\
\text { allocation and consumption }\end{array}$ & None \\
\hline & $\mathrm{H}$ & & None & None & None \\
\hline & A & & None & None & None \\
\hline \multirow{3}{*}{$\begin{array}{c}\text { Soil } \\
\text { maintenance }\end{array}$} & $\mathrm{R}$ & & Not intentional & None & None \\
\hline & $\mathrm{H}$ & & None & None & None \\
\hline & $\mathrm{A}$ & & None & None & None \\
\hline
\end{tabular}

14 